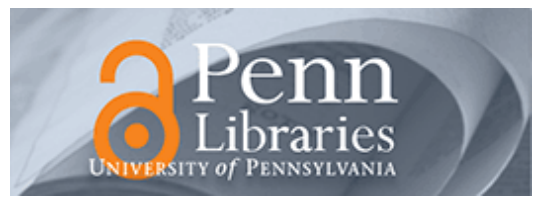

University of Pennsylvania

ScholarlyCommons

Real Estate Papers

Wharton Faculty Research

2010

\title{
The Value of School Facility Investments: Evidence From a Dynamic Regression Discontinuity Design
}

\author{
Stephanie Riegg Cellini \\ Fernando V. Ferreira \\ University of Pennsylvania \\ Jesse Rothstein
}

Follow this and additional works at: https://repository.upenn.edu/real-estate_papers

Part of the Economics Commons, and the Real Estate Commons

\section{Recommended Citation}

Cellini, S., Ferreira, F. V., \& Rothstein, J. (2010). The Value of School Facility Investments: Evidence From a Dynamic Regression Discontinuity Design. The Quarterly Journal of Economics, 125 (1), 215-261. http://dx.doi.org/10.1162/qjec.2010.125.1.215

This paper is posted at ScholarlyCommons. https://repository.upenn.edu/real-estate_papers/49

For more information, please contact repository@pobox.upenn.edu. 


\title{
The Value of School Facility Investments: Evidence From a Dynamic Regression Discontinuity Design
}

\begin{abstract}
Despite extensive public infrastructure spending, surprisingly little is known about its economic return. In this paper, we estimate the value of school facility investments using housing markets: standard models of local public goods imply that school districts should spend up to the point where marginal increases would have zero effect on local housing prices. Our research design isolates exogenous variation in investments by comparing school districts where referenda on bond issues targeted to fund capital expenditures passed and failed by narrow margins. We extend this traditional regression discontinuity approach to identify the dynamic treatment effects of bond authorization on local housing prices, student achievement, and district composition. Our results indicate that California school districts underinvest in school facilities: passing a referendum causes immediate, sizable increases in home prices, implying a willingness to pay on the part of marginal homebuyers of $\$ 1.50$ or more for each $\$ 1$ of capital spending. These effects do not appear to be driven by changes in the income or racial composition of homeowners, and the impact on test scores appears to explain only a small portion of the total housing price effect.

\section{Disciplines}

Economics | Real Estate
\end{abstract}




\title{
The Value of School Facilities:
}

\section{Evidence from a Dynamic Regression Discontinuity Design ${ }^{*}$}

\author{
Stephanie Riegg Cellini \\ The Trachtenberg School \\ George Washington \\ University
}

\author{
Fernando Ferreira \\ The Wharton School \\ University of Pennsylvania \\ and NBER
}

\author{
Jesse Rothstein \\ Department of Economics \\ Princeton University \\ and NBER
}

September 28, 2008

\begin{abstract}
This paper estimates the impact of investments in school facilities using the housing market. We draw on the unique characteristics of California's system of school finance, comparing districts in which school bond referenda passed or failed by narrow margins. We extend the traditional regression discontinuity (RD) design to account for the dynamic nature of bond referenda: the probability of future proposals depends on the outcomes of past elections. Using our "dynamic RD” estimator, we first show that bond funds stick exclusively in the capital account, with no effect on current expenditures or other revenues. We can thus interpret the effect of referendum passage as reflecting the impact of improvements in the quality of school facilities. We find that passing a referendum causes immediate, sizable increases in home prices, implying a willingness-to-pay on the part of marginal homebuyers of $\$ 1.50$ or more for each dollar per pupil of facility spending. These effects do not appear to be driven by changes in the income or racial composition of homeowners. While we find suggestive evidence that bond passage leads to increases in student test scores, this effect cannot explain more than a small portion of the housing price effect, indicating that bond passage leads to improvements in other dimensions of school output (e.g., safety) that may be not captured by test scores.
\end{abstract}

\footnotetext{
* We thank Joseph Gyourko, David Lee, Chris Mayer, Cecilia Rouse, and Tony Yezer for helpful conversations. Fernando Ferreira would like to thank the Research Sponsor Program of the Zell/Lurie Real Estate Center at Wharton for financial support. Jesse Rothstein thanks the Princeton University Industrial Relations Section and Center for Economic Policy Studies. We also thank Igar Fuki, Scott Mildrum, Francisco Novarro, and Michela Tincani for excellent research assistance.
} 


\section{Introduction}

Federal, state, and local governments spend more than $\$ 50$ billion per year to build and renovate public schools (U.S. Department of Education 2007). Despite this, many of the more than 97,000 public elementary and secondary schools in the United States are in need of renovation, expansion, and repair: fully one-third of public schools rely on portable or temporary classrooms and one-quarter report that environmental factors, such as air conditioning and lighting, are "moderate" or "major" obstacles to instruction (U.S. Department of Education 2007, Table 98). Notwithstanding, little is known about the importance of facility quality to educational production.

Two central difficulties plague the literature on the effects of school resources, ${ }^{1}$ both applicable to the effects of capital spending as well. First, resources may be endogeneous to schooling outcomes. The few studies ${ }^{2}$ that have focused explicitly on the effects of capital expenditures on student achievement are unable to convincingly separate the causal effects of school facilities from other confounding factors, such as the socioeconomic status of local families. Second, many of the effects of resources may be reflected only imperfectly in student achievement, so even a credible causal estimate of the effect on test scores might miss many of the benefits. This seems likely to be a particular problem for school facilities, for which the benefits may be concentrated in nonacademic outcomes like student health and safety.

This latter challenge is often avoided by focusing on the impacts of school spending on housing markets. If homebuyers value school spending at the margin more than they value the taxes they will pay to finance it, spending increases should lead to increases in housing prices. ${ }^{3}$ Indeed, in standard Tiebout (1956)-style models, a positive effect of tax increases on spending is direct evidence that the prior spending level was inefficiently low. As in studies of the effects of resources on achievement, however, causal identification is quite challenging.

\footnotetext{
${ }^{1}$ Hanushek (1996) reviews more than 90 studies and 400 estimates of the impact of school resources on achievement and concludes that "[s]imple resource policies hold little hope for improving student outcomes". Card and Krueger (1996) dispute Hanushek's interpretation of the literature. See also Hanushek (1986, 1997); Card and Krueger (1992); and Heckman, Layne-Farrar and Todd (1996).

${ }^{2}$ See, e.g., Jones and Zimmer (2001); Schneider (2002); and Uline and Tschannen-Moran (2008).

${ }^{3}$ See Oates (1969); Dee (2000); Palmon and Smith (1998); Starrett (1981); Barrow and Rouse (2004); and Bradbury, Mayer and Case (2001). A related body of research uses housing markets to measure household willingness to pay for school quality. See Rosen (1974) for an economic interpretation of the hedonic model, and Black (1999); Bayer, Ferreira, and McMillan (2007); Kane, Riegg, and Staiger (2006); and Rothstein (2006) for empirical applications.
} 
This paper reports estimates of the causal effects of school facility spending on both home values and student achievement. We implement a new research design that takes advantage of the unique characteristics of California's school finance system to isolate exogenous variation in spending. While most school finance in California is extremely centralized and offers little local discretion, California school districts can issue general obligation bonds to finance the construction, improvement, and maintenance of school facilities. ${ }^{4}$ Proposed bond measures must be approved in local referenda, and districts that approve bond issues are likely to differ on both observable and unobservable dimensions from those that do not. Districts in which bonds pass or fail by very narrow margins, however, are likely to be quite similar on average. Taking advantage of the underlying continuity in district characteristics around the threshold for bond approval, we use a regression discontinuity (RD) framework to identify the causal impact of bond funding. ${ }^{5}$ To implement this design, we assemble a rich data set combining referenda outcomes with annual district-level measures of house prices, school district expenditures, and student test scores spanning two decades.

Several previous papers have used elections as sources of identification in RD models. ${ }^{6}$ Our analysis is complicated by the dynamic nature of the bond proposal process: a district that passes a bond measure this year is unlikely to consider or pass another measure next year. Conversely, districts that narrowly reject initial proposals are likely to consider new proposals in the next election cycle, and these are quite likely to pass. Specifications that do not take account of these dynamics yield attenuated estimates of the effect of bond spending. We extend the RD strategy to panel data with endogenous repeated elections. Our innovative "dynamic RD” model leverages the power of the RD design to provide well-identified estimates of the full dynamic structure of the effects of bond funds on fiscal, academic and housing market outcomes.

Although the bond-funded revenue we study is earmarked for local capital improvements, theory predicts that districts will find ways to divert resources toward non-capital purposes. ${ }^{7} \mathrm{We}$ find no evidence of this - bond revenues appear to stick entirely in the local capital account and we reject even small effects on either current spending or other revenue sources. This strong

\footnotetext{
${ }^{4}$ Voter approved bonds are also common in other states, including Massachusetts, Ohio, Pennsylvania and Florida.

${ }^{5}$ Early discussions of the RD design include Thistlethwaite and Campbell (1960) and Cook and Campbell (1979).

For recent overviews, see Hahn, Todd, and Van der Klaauw (2001) and Imbens and Lemieux (2007).

${ }^{6}$ See, e.g., Lee (2001, 2008), Lee, Moretti, and Butler (2004), DiNardo and Lee (2004), Cellini (2007), PetterssonLidbom (2008), and Ferreira and Gyourko (2009).

${ }^{7}$ See, e.g., Bradford and Oates (1971a, 1971b) and Knight (2002).
} 
flypaper effect allows us to interpret of our estimates of the impact of bond passage as the effects of school facility investments.

We find that passage of a bond leads housing prices in the district to rise by approximately three percentage points immediately, rising to about twice that within three years. This effect appears to last for at least a decade. Our estimates imply that marginal homebuyers are willing to pay substantially more than $\$ 1$, via higher purchase prices and expected future property taxes, for future school spending with present discounted value of $\$ 1$. Even under the most conservative assumptions, the willingness-to-pay is never smaller than \$1.30, and our preferred estimates are $\$ 1.50$ or more. The implied elasticity of home prices with respect to school spending is approximately 0.5 . This is slightly higher than, but consistent with, elasticities obtained by previous studies of unrestricted spending.

We find little evidence of changes in the income or racial composition of local homebuyers following the passage of a bond. However, we find suggestive evidence that bond passage leads to higher student achievement, albeit with a long lag: both math and reading test scores increase by 0.07 of a student-level standard deviation by the sixth year after a bond passage. While substantial, this result is not entirely robust - although the $6^{\text {th }}$ year effect is individually significant, we cannot reject that all lagged effects are zero. Moreover, even effects as large as our $6^{\text {th }}$ year estimate can explain only a small portion of the price effect of bond passage. Evidently, much of the value of school facilities to homeowners derives from dimensions of school output that are not reflected in student test scores. This highlights the importance of using housing markets - rather than simply test score gains - to evaluate school investments.

Our results provide clear evidence that school districts under-invest in school facilities, as homebuyers value a dollar of school facility spending at much more than $\$ 1$. While much of the public choice literature emphasizes the potential for over-spending by "Leviathan" governments, our results suggest that the opposite is the case. Caution is required, however, in attempting to generalize these results beyond our sample: California has unusually low school spending, particularly in the capital account, and marginal returns may be lower in other states. Even within California effects may differ for districts that are not at the margin of approving a bond issue. Nevertheless, finding that investments in school facilities have a positive impact on housing prices and (perhaps) student achievement is an important result. It also suggests that 
California-style restrictions on local public good provision have important efficiency costs, and that school spending levels may be too low.

The remainder of the paper is organized as follows: Section II describes the California school finance system. Section III develops simple economic models of resource allocation and capitalization. Section IV details our research design. Section V describes the data, Section VI validates our regression discontinuity strategy, and Section VII presents our estimates. Section VIII concludes.

\section{California School Finance}

California was historically known for its high-quality, high-spending school system. By the 1980s and 1990s, however, California schools were widely considered underfunded. By 1995, per-pupil current spending had fallen to 13 percent below the national average, ranking the state $35^{\text {th }}$ in the country despite its relatively high costs. Capital spending has been particularly stingy, 30 percent below the national average in $1995 .{ }^{8}$ California schools are notorious for their overcrowding, poor physical conditions, and heavy reliance on temporary, modular classrooms (see, e.g., New York Times 1989, Sebastian 2006).

Much of the decline in school funding has been attributed to the state's shift to a centralized system of finance under the 1971 Serrano v. Priest decision and to the passage in 1978 of Proposition 13, which eliminated school districts' flexibility to set tax and spending levels and, moreover, starved the state of revenue with which to assist districts. ${ }^{9}$ In 1984, however, voters approved Proposition 46. The Proposition allowed school districts to issue general obligation bonds to finance capital projects and to raise the local property tax rate for the duration of the bonds in order to pay them off. ${ }^{10}$ Bonds must be approved by referendum. Initially, a 2/3 vote was required, but beginning in 2001 proposals that adhered to certain restrictions could qualify for a reduced threshold of 55\%. Brunner and Reuben (2001) attribute

\footnotetext{
${ }^{8}$ Statistics in this paragraph are computed from U.S. Department of Education (2007), Table 174, and U.S. Department of Education (1998), Tables 165 and 42.

${ }^{9}$ See Fischel (1989), Shapiro and Sonstelie (1982) and Sonstelie, Brunner, and Ardun (2000) for further details and discussion of California's school finance reforms.

${ }^{10}$ Local electorates can also approve parcel taxes for school funding, though these are comparatively rare. Parcel tax revenues have much fewer restrictions than school bonds (Orrick 2004, p.1). Although we focus on general obligation bonds in the analysis below, we present some specifications that incorporate parcel taxes as well.
} 
$32 \%$ of California school facility spending between 1992-93 and 1998-99 to local bond referenda. The leading alternative source of funds was state aid. ${ }^{11}$

The ballot summary for a representative proposal reads:

Shall Alhambra Unified School District repair, upgrade and equip all local schools, improve student safety conditions, upgrade electrical wiring for technology, install fire safety, energy efficient heating/cooling systems, emergency lighting, fire doors, replace outdated plumbing/sewer systems, repair leaky rundown roofs/bathrooms, decaying walls, drainage systems, repair, construct, acquire, equip classrooms, libraries, science labs, sites and facilities, by issuing $\$ 85,000,000$ of bonds at legal rates, requiring annual audits, citizen oversight, and no money for administrators' salaries? (Institute for Social Research 2006)

Bond revenues must go to pre-specified capital projects (CA Legislative Information Website 2006). Anecdotally, bonds are frequently used to build new permanent classrooms that replace temporary buildings (Sebastian 2006a, 2006b) and to provide facilities needed to expand from half-day to full-day kindergarten (DiMassa 2003). But repair and maintenance are also permissible uses, raising the possibility that districts that were previously funding maintenance out of unrestricted funds might divert those funds to other purposes when bonds are approved.

629 of the 1,035 school districts in California voted on at least one bond measure between 1987 and 2006. ${ }^{12}$ The average number of measures per school district considered over this period was slightly over two. ${ }^{13}$ Many of the elections were close: $35 \%$ of all bond measures had margins of victory or defeat of less than 5 percentage points. Table 1 shows the number of measures proposed and passed in each year, along with the average bond amount (in $2000 \$$ per pupil), the distribution of required vote shares for bond approval, and the mean and standard deviation of observed vote shares.

Balsdon, Brunner, and Rueben (2003) study the decision to propose and pass a bond measure. We add one point to their discussion: California's unique property tax rules affect voters' incentives regarding bond measures. Under Proposition 13, assessed values are frozen at the most recent sale price. This means that older families face disincentives to move after children leave the home (Ferreira 2007), which may reduce willingness to support the public

\footnotetext{
${ }^{11}$ The state aid programs target districts based on building age and capacity. If local revenues are used to expand capacity or replace old school buildings, bond passage may reduce the district's eligibility for state aid. We investigate this empirically below.

${ }^{12}$ These data come from the California Education Data Partnership. More details are provided in Section V.

${ }^{13} 264$ districts had only one measure on the ballot between 1987 and 2006, while 189 districts had 2 measures, 99 districts had 3 measures, 53 districts had 4 measures, and 30 districts had 5 or more measures. The maximum was 10 measures.
} 
schools. There is also substantial variation within districts in the tax price of local spending, as new buyers pay a share of any tax increases that is far out of proportion to their share of the district's total property values. We discuss implications of these incentives below.

\section{Theoretical Framework}

\section{A. School Resources and Flypaper Effects}

Studies of school resources often invoke an "educational production function" that links school resources - facilities, teacher quality, and class size, for example — to measurable student outcomes. If school districts allocate resources optimally to their most productive uses, exogenous increases in unrestricted school funding should improve student outcomes. Evidence that resources do not affect outcomes has often been taken as an indication that schools are inefficiently managed (e.g., Hanushek 1986, 1997).

In theory, it should not matter whether marginal resources are restricted to certain purposes, such as capital expenditures: districts will simply divert unrestricted funds away from those targeted categories, with no effect on the total allocation. The only exception would arise if the districts are at a corner solution, devoting none of their unrestricted funds to the targeted categories. We develop a simple model illustrating this in Appendix A.

Despite this well-known, widely accepted theory, a large body of evidence documents an empirical anomaly: restricted grants tend to stick, even when the pre-grant allocation to the targeted account is non-zero. This so-called "flypaper" effect is well documented in a variety of settings, most notably in the context of intergovernmental grants (e.g. Bradford and Oates 1971a, 1971b). ${ }^{14}$ Knight (2002), however, has challenged the evidence for flypaper effects, arguing that most papers do not adequately account for the endogeneity of intergovernmental grants.

Our regression discontinuity design represents a solution to this endogeneity problem, and permits us to identify the causal effect of restricted funding on both resource allocations and other revenues (e.g. state aid). In the empirical application we further distinguish between districts where prior spending patterns indicate that the restriction should or should not be

\footnotetext{
${ }^{14}$ Gordon (2004) finds that flypaper effects of intergovernmental grants are short-lived, but Barrow and Rouse (2004) find persistent effects. Flypaper effects have also been documented in corporate finance (Kaplan and Zingales 1997) and, more recently, in intra-household consumption (Duflo and Udry 2004), and individual investment decisions (Choi, Laibson, and Madrian 2007). See Hines and Thaler (1995) for a survey.
} 
binding. We find strong evidence of flypaper effects for both sets of districts, and are able to reject even small spillovers and crowd-out effects.

These results imply that our analysis of earmarked bonds will identify the impact of a specific type of school resource-school facilities. It is an open question whether capital improvements will lead to improved student achievement. Education researchers and reformers often cite overcrowded classrooms; poor ventilation, indoor air quality, temperature control, or lighting; inadequate computer hardware or wiring; and broken windows or plumbing, as problems that can interfere with student learning. Mitigating these types of environmental conditions may bring substantial gains to student achievement in the short-run by reducing distractions and missed school days (see Earthman 2002, Mendell and Heath 2004, and Schneider 2002 for reviews of this literature). Improved conditions may also benefit teachersreducing absenteeism, improving morale, and potentially reducing turnover (Buckley, Schneider, and Shang, 2005) - all of which may in turn impact student achievement (e.g. Clotfelter, Vigdor, and Ladd 2007). But direct evidence regarding the effects of investments in school facilities is in extremely short supply.

Importantly, the services provided by capital investments may be reflected only imperfectly in student test scores. Infrastructure improvements may produce improvements in student safety, athletic and art training, or the aesthetic appeal of the campus, all of which may be valued by parents or homeowners, without any effect on academic achievement.

\section{B. Voting, Housing Prices and the Value of School Facilities}

One way to sidestep the challenges inherent in the measurement of school outputs is to focus on the revealed preferences of parents and homeowners, as seen in housing markets. Local net-of-tax housing prices should reflect the utility that home-buyers derive from the full menu of local public goods. In this study, we examine compensated funding shifts, additional revenues that are accompanied by an increased tax burden. Thus, if funds are misspent or simply yield smaller benefits than would the consumption that must be foregone due to increased taxes, pretax housing prices should fall when bond proposals pass. By contrast, if the effect on school output is valued more than the foregone non-school consumption, home prices will rise when bonds are passed. It can be shown that the efficient choice of spending levels will equate the marginal utility of consumption with that of school spending, so positive price effects imply that the prior spending level was inefficiently low. 
The development of a full equilibrium model of house prices, household location decisions and provision of local public goods is beyond the scope of this paper. ${ }^{15}$ We merely provide a bit of intuition regarding the factors that determine home price effects due to exogenous school investments. Among other simplifications, we neglect heterogeneity in residents' tax shares and within-community variation in the amount of housing consumed. We assume that the utility of family $i$ living in district $j$ depends on local school output $A_{j}$, exogenous amenities $X_{j}$, and other consumption $c_{i}: u_{i j}=U_{i}\left(A_{j}, X_{j}, c_{i}\right)$. The consumer has income $w_{i}$ and faces the budget constraint $c_{i} \leq w_{i}-r_{j}-p_{j}$, where $r_{j}$ represents the property taxes needed to fund school operations and $p_{j}$ is the (rental) price of local housing. Service quality depends on tax revenues, $A_{j}=A\left(r_{j}\right)$; if districts use funds inefficiently, $A^{\prime}(r)$ will be low.

We first discuss the household location decision, taking spending as given, and then discuss the preferences of voters. A family chooses the community that provides the highest utility, taking into account housing prices, taxes, and service quality. Writing the family's indirect utility in district $j$ as $U\left(A\left(r_{j}\right), X_{j}, w_{i}-r_{j}-p_{j}\right)$, the implicit function theorem yields the family's bid for housing in district $j$ as a function of amenities and taxes, $g_{i j}=g_{i}\left(X_{j}, r_{j}\right){ }^{16}$ This bid-rent function depends on the prices, amenities, and tax rates of all other communities in the family's choice set; taking these as given, community $j$ will provide higher utility than any alternative community so long as $p_{j}<g_{i j}$.

The family's willingness-to-pay (WTP) for a marginal increase in $r_{j}$ in its chosen district is $\partial g_{i}\left(X_{j}, r_{j}\right) / \partial r_{j}$. It can be shown that

$$
\text { (1) } \quad \partial g_{i}\left(X_{j}, r_{j}\right) / \partial r_{j}=(\partial U / \partial c)^{-1}\left[A^{\prime}\left(r_{j}\right) *(\partial U / \partial A)\right]-1 .
$$

This value will be positive if and only if the marginal product of school revenues multiplied by the marginal utility of school outputs (in brackets) is greater than the marginal utility of consumption. Ignoring momentarily the effect of spending on local housing prices, the family's optimal tax and service level satisfies $\partial g_{i}\left(X_{j}, r_{j}\right) / \partial r_{j}=0$. If $\partial g_{i}\left(X_{j}, r_{j}\right) / \partial r_{j}>0$, the district's spending is below the family's preferred level; if $\partial g_{i}\left(X_{j}, r_{j}\right) / \partial r_{j}<0$, the family would prefer that taxes and services be cut.

\footnotetext{
${ }^{15}$ The basic model is due to Brueckner $(1979,1982,1983)$. Barrow and Rouse (2004) provide an accessible discussion. For more complex models that incorporate Tiebout sorting and voting, see Epple, Filimon and Romer (1984, 1993), Benabou (1993) and Nechyba (1997).

${ }^{16} G_{i}\left(r_{j}\right)$ is defined implicitly by $U\left(A\left(r_{j}\right), X_{j}, w_{i}-r_{j}-g_{i}\left(X_{j}, r_{j}\right)\right)=\max _{k \neq j} U\left(A\left(r_{k}\right), X_{k}, w_{i}-r_{k}-p_{k}\right)$.
} 
In equilibrium, the price of housing in district $j$ equals the bid of the marginal consumer, who must be indifferent between this district and another alternative. Thus, local housing prices, $p^{*}\left(X_{j}, r_{j}\right)$, will respond positively to increases in $r$ if and only if the prior level of school spending was below the preferred level of the marginal resident.

When a tax increase does take place, low-WTP residents will tend to leave the community and be replaced by in-movers with higher WTP. Tiebout-style models typically assume that higher-income families have higher willingness-to-pay for school quality. Thus, tax increases may lead to increases in the mean income of district residents. Because $A$ depends directly on community composition, $\mathrm{d} A / \mathrm{d} r$ will reflect both the direct effect of spending on achievement and an indirect effect operating through effects of $r$ on the characteristics of the district's students. House prices will reflect both, plus an additional component if families directly value high income neighbors (Bayer, Ferreira and McMillan, 2004). In the empirical analyses below we test for residential sorting by investigating the effects of bond passage on both the income and race of new homebuyers and on school district demographics.

Tax changes are not exogenous, but depend on election outcomes. For example, absentee landlords should vote for any proposal that would lead to an increase in housing rents. Thus, to the extent that spending levels are set by such landlords, taxes will be set at the property-valuemaximizing level. The first-order effect of an exogenous change in tax rates will be zero, and the second-order effect negative. But absentee landlords do not vote; residents do. There are several circumstances in which residents will oppose spending increases even though $\partial p^{*}\left(X_{j}\right.$, $\left.r_{j}\right) / \partial r_{j}>0$. Most obviously, any renter who values spending less than the marginal resident - for whom $\partial g_{i}\left(X_{j}, r_{j}\right) / \partial r_{j}<\partial p^{*}\left(X_{j}, r_{j}\right) / \partial r_{j}$ - will vote against a proposed spending increase, as the utility she will derive from higher spending will not compensate her for the increased rent that she will pay. Similarly, a homeowner who does not wish to move will vote on the basis of her own bid-rent, not the community's price function, and will oppose a tax increase if $\partial g_{i}\left(X_{j}, r_{j}\right) / \partial r_{j}$ $<0$. Thus, in general we should not expect that equilibrium spending levels will satisfy $\partial p^{*}\left(X_{j}\right.$, $\left.r_{j}\right) / \partial r_{j}=0$.

There are several aspects of California's tax and school finance system that will tend to lead to under-provision relative to the preferences of marginal residents. First, property valuations are frozen at the initial sale price. Where in other states "empty nesters" whose kids have grown will tend to move to a smaller house in a low-service community, in California they 
face strong incentives to remain in their original homes. Immobile empty nesters will almost certainly oppose spending increases, as they derive little direct utility from school spending and see only paper gains from increases in local housing prices. Second, California's school finance is extremely centralized, and local residents have little control over spending. Hoxby (2001) argues that California-type systems will tend to lead to under-provision, at least in wealthy communities. If so, houses in high-spending districts are under-supplied, and exogenous increases in $r$ will lead to higher prices.

A final issue concerns timing. Capital projects take time to plan, initiate, and carry out, so bonds issued today will take several years to translate into improved capital services. Thus, direct measures of school outputs will reflect the effects of bond passage only with long lags. But current house prices reflect the present discounted value of all future services less all future taxes, so should rise or fall as soon as the outcome of the election is known. ${ }^{17}$ This may happen well before the election if the outcome is easy to predict, but when the election is close there is likely important information revealed on election day.

\section{Empirical Research Design}

\section{A. Regression Discontinuity}

In general, school districts with higher test scores and graduation rates also have higher property values, lower tax prices of school spending, and residents with greater willingness to pay for school quality. The resulting correlation between school quality and locally funded spending cannot be interpreted causally.

California's bond referenda provide a source of variation that can be used to overcome the endogeneity of school spending. The use of vote shares in a regression discontinuity design was first developed by Lee $(2001,2008)$. Lee demonstrates that comparing bare losers with bare winners provides quasi-random variation in winner status, since for narrowly decided races the outcome is unlikely to be correlated with other district characteristics as long as there is some unpredictable component of the ultimate vote. That is, if $v_{j}$ is the vote share and $v^{*}$ is the

\footnotetext{
${ }^{17}$ By design, bonds decouple the timing of tax revenue from spending. This can create complex post-election price dynamics. We discuss these in an Appendix. The basic point that the net value of the bond-financed spending relative to the taxes needed to pay for it is capitalized on or before the date of the election is unchanged.
} 
threshold required for passage, unobserved district characteristics $\mu_{j}$ may vary with $v_{j}$ but should be similar for districts with $v_{j}=v^{*}+\varepsilon$ and $v_{j}=v^{*}-\varepsilon$ (for small $\varepsilon$ ).

Formally, the required assumption is that $E\left[\mu_{j} \mid v_{j}\right]$ is continuous at $v_{j}=v^{*}$. If we assume

$$
y_{j}=\alpha+b_{j} \beta+\mu_{j}
$$

where $b_{j}$ is an indicator for bond passage (i.e. for $v_{j} \geq v^{*}$ ) and $y_{j}$ is some outcome, we can write

$$
E\left[y_{j} \mid v_{j}\right]=\alpha+E\left[b_{j} \mid v_{j}\right] \beta+E\left[\mu_{j} \mid v_{j}\right]=\alpha+b_{j} \beta+E\left[\mu_{j} \mid v_{j}\right] .
$$

Then the assumed continuity of $E\left[\mu_{j} \mid v_{j}\right]$ at $v^{*}$ implies that:

$$
\lim _{v_{j} \downarrow v^{*}} E\left[y_{j} \mid v_{j}\right]-\lim _{v_{j} \uparrow v^{*}} E\left[y_{j} \mid v_{j}\right]=\beta
$$

There are several available strategies for consistently estimating the discontinuity in $E\left[y_{j} \mid\right.$ $\left.v_{j}\right]$ at $v^{*}$. First, one can focus narrowly on the region around $v^{*}$ to estimate $E\left[y_{j} \mid v^{*}-\varepsilon<v_{j}<v^{*}\right]$ and $E\left[y_{j} \mid v^{*} \leq v_{j}<v^{*}+\varepsilon\right]$, discarding observations with vote shares far from $v^{*}$. This consistently estimates $\beta$ so long as $\varepsilon$ shrinks toward zero as the sample size grows. A second strategy uses all of the data, but approximates $E\left[\mu_{j} \mid v_{j}\right]$ with a polynomial expansion:

$$
E\left[y_{j} \mid v_{j}\right]=\alpha+b_{j} \beta+\gamma_{0}+v_{j} \gamma_{l}+\ldots+v_{j}^{k} \gamma_{k} .
$$

If the polynomial in $v_{j}$ is sufficiently flexible, it should absorb any correlation between unobservables and the bond passage indicator. This polynomial strategy is consistent if the order of the polynomial, $k$, rises with the sample size. ${ }^{18}$ The benefit of the polynomial expansion approach is that it allows use of all of the data, even while asymptotically identifying $\beta$ only from observations with $v_{j}$ close to $v^{*}$. This becomes useful when we consider the dynamics of bond proposal and passage, as a district that has multiple elections may see a close vote in one but not in the others.

\section{B. Panel Data and the Dynamic RD}

We have annual observations on our outcome measures, and bonds may affect outcomes with long lags. Let $\beta_{\tau}$ be the effect of passing a measure in year $t$ - $\tau$ on outcomes measured in year $t$, with $\beta_{\tau}=0$ for $\tau \notin[0, \bar{\tau}]$. Let $b_{j, s}$ be an indicator for whether district $j$ passed a measure in year $s$. Then the data generating process for the outcome in year $t$ can be written as:

\footnotetext{
${ }^{18}$ The polynomial approximation strategy requires only one assumption beyond those required for the narrow window strategy: That $\mathrm{E}\left[\mu_{j} \mid v_{j}\right]$ is continuous everywhere, rather than just in a region around $v^{*}$.
} 


$$
y_{j t}=\alpha+\sum_{\tau=0}^{\bar{\tau}} b_{j, t-\tau} \beta_{\tau}+\mu_{j t}
$$

$\mu_{j t}$ may have district-specific, time-specific, and idiosyncratic components: $\mu_{j t}=u_{j}+\omega_{t}+v_{j t}$. Any or all of these may be correlated with the $b_{j, s}$ sequence.

We take two approaches to adapting the RD model to panel data, distinguished by the way that repeated measures in the same district are handled. First, in what we refer to as our "static RD" estimator, we treat each measure separately. For each measure in district $j$, we select all observations from district $j$ from two years before the election to six years after, irrespective of whether there were other measures in the interim. Defining the year of the election as $t_{0}$ and the relative year as $\tau \equiv t$ - $t_{0}$, we estimate the following regression:

$$
y_{j t \tau}=b_{j, t_{0}} \gamma_{\tau}+P_{\tau}\left(v_{j, t_{0}}\right)+\alpha_{j, t_{0}}+\delta_{t}+\lambda_{\tau}+u_{j t \tau} .
$$

Here, $b_{j, t_{0}}$ is the outcome of the measure (pass or fail), and $v_{j, t_{0}}$ is the vote share. $P_{\tau}()$ is a polynomial (e.g., a cubic). Both the $\gamma_{\tau}$ coefficients and those of the $P_{\tau}$ polynomial vary freely with $\tau . \quad \lambda_{\tau}$ and $\delta_{t}$ are fixed effects for relative and absolute years, respectively.

Our preferred specification of the static RD model includes measure fixed effects $\left(\alpha_{j, t_{0}}\right)$ and constrains the $\gamma_{\tau}$ and $P_{\tau}$ coefficients to zero for $\tau<=0 .{ }^{19}$ The balance of outcomes before the election - as one would expect from the RD design - means that the measure fixed effects are unnecessary for identification. We nevertheless include them as they absorb important heterogeneity and allow for much more precise estimates. ${ }^{20}$ Also, as discussed in Section II, $v^{*}$ varies across measures - some require a $55 \%$ vote and others a $67 \%$ vote to pass. We include in (7) a control for $v^{*}$ (allowing the coefficient to vary with $\left.\tau\right){ }^{21}$

Note that observations may appear more than once in our static RD sample, linked to different measures. For example, if a district had elections in 2000 and 2002, its 2004 outcomes would appear both for the first election (with $\tau=4$ ) and for the second (with $\tau=2$ ). We cluster by school district to account for the dependence that this creates.

\footnotetext{
${ }^{19}$ For house price regressions we allow $\gamma_{0}$ and $\mathrm{P}_{0}(v)$ to be non-zero as well, since passage may have immediate effects on prices. We have also tried excluding the measure effects and estimating the $\gamma_{\tau}$ and $P_{\tau}$ coefficients even $\tau<0$. This is a specification test: measure passage should not have effects before the election (Rothstein, 2008). Indeed, our estimates of $\gamma_{\tau}$ are small and insignificant for $\tau<0$.

${ }^{20}$ On the use of fixed effects in standard RD estimates, see Petterssom-Lidbom (2007).

${ }^{21} \mathrm{We}$ also use the variation in $v^{*}$ to form a specification check for the assumption that unobserved district characteristics are continuous at $v^{*}$ : we look for evidence that $\mathrm{E}[y \mid v]$ is discontinuous at $v=0.55$ when the threshold was $67 \%$, and vice versa.
} 
Equation (7) can be seen as a reduced form for (6) in which the $\gamma_{\tau}$ coefficients capture both the direct effects of bond passage at lag $\tau\left(\beta_{\tau}\right.$ in (6)) and indirect effects of passage in year $t_{0}$ on the likelihood of passing further measures in the intervening years $\left\{t_{0}+1, \ldots, t\right\}$. These indirect effects can be represented by $\sum_{s=0}^{\tau-1}\left(\mathrm{~d} b_{j, t-s} / \mathrm{d} b_{j, t-\tau}\right) \beta_{s}$, where $\mathrm{d} b_{s} / \mathrm{d} b_{t}$ is the effect of measure passage in year $t$ on other bond measure passage in year $s$. We show in Section VI that empirically, $\mathrm{d} b_{s} / \mathrm{d} b_{t}$ is negative and fairly large: one consequence of passing a measure today is to reduce the likelihood of passing a measure in the next few years. Therefore, so long as the lagged effects $\beta_{s}$ all have the same sign, we expect (7) to under-estimate the true lagged effects.

$\mathrm{RD}$ analyses of repeated elections frequently model those after the first as sources of noncompliance in the quasi-experiment created by the first election. This can motivate an instrumental variables strategy, in which passage of the first measure is used as an instrument for an indicator for whether any measure was ever passed, conditional on flexible controls for the first election vote share. ${ }^{22}$ This IV approach is predicated on the assumption that an "ever passed a measure" indicator can summarize the treatment history. It is therefore poorly suited to the task of obtaining estimates of the unrestricted lagged treatment effects in (6).

To obtain estimates that are interpretable as the true lagged effects in the presence of multiple elections, we turn to our second strategy, which we refer to as a "dynamic RD" specification. To our knowledge this is the first regression discontinuity application that incorporates dynamic treatment effects. We use the full panel of observations on districts over time, including each observation exactly once. We form an indicator, $m_{j, s}$, for whether district $j$ had a measure on the ballot in year $s$, and we set $b_{j, s}=v_{j, s}=0$ whenever $m_{j, s}=0$. We then regress outcomes on a full set of lags of $m, b$, and a polynomial in $v$, allowing all coefficients to vary freely with $\tau$ :

$$
y_{j t}=\sum_{\tau=0}^{\bar{\tau}}\left(m_{j, t-\tau} \lambda_{\tau}+b_{j, t-\tau} \theta_{\tau}+P_{\tau}\left(v_{j, t-\tau}\right)\right)+\alpha_{j}+\delta_{t}+u_{j t} .
$$

\footnotetext{
${ }^{22}$ This can be seen as a "fuzzy" RD design, as described by Hahn, Todd, and Van der Klaauw (2001). Our static $\mathrm{RD}$ model, which ignores future elections, can be seen as the reduced form for the IV regression. See Lee, Moretti and Butler (2004) for a related application where repeated elections have known lags.
} 
We include time effects $\left(\delta_{t}\right)$ to absorb changes in the price level. The district fixed effects $\left(\alpha_{j}\right)$ absorb persistent differences across districts that are unrelated to bond passage. ${ }^{23}$

Relative to (7), (8) can be seen as controlling for intermediate outcomes: passage of a bond in year $t_{0}$ may influence $m_{j, s}$ and $v_{j, s}$ for any $s>t_{0}$. Under the standard RD assumption that measure passage is as good as randomly assigned conditional on a smooth function of $v_{j, s}$, any influence of past elections on $b_{j, s}$ itself should be absorbed through the $P_{\tau}\left(v_{j, s}\right)$ polynomial. The $\theta_{\tau}$ coefficients can therefore be interpreted as consistent estimates of the causal effects of bond passage at lag $\tau$, net of any effects operating through successive bond proposals and votes. ${ }^{24}$

\section{Data}

Bond and parcel tax data are drawn from a database maintained by the California Education Data Partnership. The data include year of the measure, bond amount, its intended purpose, vote shares, required vote shares for passage of the measure, and voter turnout. Our sample includes all general obligation bond measures sponsored by school districts between 1987 and 2006. We merge these to district-level enrollment, revenue, and spending data from the Common Core of Data (CCD). The data contain annual measures of capital and current expenditures, revenues, and long-term debt between 1995 and 2006. We also extract from the CCD the number of schools, enrollment, and student demographics, each measured annually. ${ }^{25}$

We obtain annual average home prices (averaged over all transactions) and other characteristics of transacted homes (square footage and lot size) at the census block group level from a proprietary database. The data, compiled from public records by the real estate services firm Dataquick, describes all housing transactions in California from 1988 to $2005 .{ }^{26}$ We used GIS mapping software to assign census block groups to school districts. ${ }^{27}$

\footnotetext{
${ }^{23}$ As in the static specification, we have also estimated versions of (8) that omit the district fixed effects and estimate the $\lambda_{\tau}, \theta_{\tau}$, and $P_{\tau}$ coefficients even for $\tau<0$.

${ }^{24}$ Even our dynamic RD can be seen as a reduced form estimate, as we do not control for all of the other intervening events - superintendent and mayoral elections, changes in state aid, etc. - that may be influenced by bond passage. We also focus on the simple effect of bond passage, rather than the effects of the particular uses to which the bond revenues are put (e.g. window repairs, lighting improvements, new construction, etc.).

${ }^{25}$ Some districts merge or split in two during our sample period. Where possible, we combine observations to form a consistent unit over time, adding the spending and enrollment data for the constituent districts.

${ }^{26}$ The majority of housing transactions happen from May through August. We assign measures to housing data treating the year containing the first summer after the measure election as the year of the election. Thus, an election in November 2005 is treated as occurring in the same year as housing transactions from 2006. To merge measures
} 
Our prices reflect only houses that sell during the year. If the mix of houses that transact changes - for example, one might expect sales of houses that can accommodate families with children to react differently to school spending than do smaller houses - this will lead our measures to be biased relative to the quantity of interest, the prices of all houses in the district. We take two steps to minimize this bias. First, when we average block groups to the district level, we weight them by their year-2000 populations rather than by the number of transactions. ${ }^{28}$ This ensures the location of transactions within the district is held constant. Second, we include in our models of housing prices several control variables that may help to absorb differential selection: the average size (square footage) and lot size of transacted homes as well as the number of sales.

Our test score data merge results from several different tests. From 2003 to 2007, the most consistently available measures of student achievement are third grade reading and math scores on the California Achievement Tests (CAT). The most comparable measures in earlier years are based on the Stanford-9 exam, given each year between 1998 and 2002. Though they were developed by different publishers and therefore not directly comparable, both the CAT and Stanford-9 exams are nationally-normed multiple-choice exams. Before 1998, test score data are more limited. We use California Learning Assessment System (CLAS) reading and math test scores for fourth graders for 1993 and 1994. To account for differences in exams across years, we standardize the scaled scores each year using school-level means and standard deviations.

Finally, we constructed the racial composition and average family income of homebuyers in each district between 1992 and 2006 from data collected under the Home Mortgage Disclosure Act (HMDA). We use a GIS matching procedure similar to the one implemented for house prices to map the tract-level HMDA data to school districts. We treat our measure as characterizing in-migrants to the district, though we are unable to exclude intra-district movers from the calculation. Note also that renters are not represented in these data.

Table 2 presents descriptive statistics for all variables described above. Column 1 shows the means and standard deviations computed over all district-year observations in our data.

to academic-year data from the CCD, we treat any measure between May 2005 and April 2006 as occurring during the 2005-06 academic year.

${ }^{27}$ When school district boundaries and block group boundaries do not line up we use population weights based on the proportion of a block group located within a school district.

${ }^{28}$ Our results are robust to other schemes for weighting blocks within districts. 
Columns 2 and 3 divide the sample between districts that proposed at least one measure from 1987 to 2006 and those that did not. Districts that proposed measures are larger than those that did not and have higher test scores, incomes, and housing prices, but smaller lot sizes.

Columns 4 and 5 focus on districts that approved and rejected school bonds, using data from the year just before the bond election, while column 6 presents differences between them. Districts that passed measures had 26\% higher enrollment, \$557 more in debt per pupil, and \$200 higher current instructional spending, although this is somewhat offset by a smaller \$163 in construction outlays. Total per-pupil expenditures are similar. Districts that passed measures also had higher house prices and incomes.

\section{Testing the Validity of the Regression Discontinuity Design}

\section{A. Balance of Treatment and Control Groups}

In light of the large pre-existing differences between districts that pass and fail measures, it is important to verify that our regression discontinuity design can eliminate these differences. We examine three diagnostics for the validity of the RD quasi-experiment, based on the distribution of vote shares, pre-election differences in mean outcomes, and differences in preelection trends. Tests of the balance of outcome variable means and trends before the election are possible only because of the panel structure of our data, and provide particularly convincing evidence regarding the approximate randomness of measure passage.

Figure 1 shows the histogram of bond measure vote shares, separately for measures that require $2 / 3$ and $55 \%$ of the vote. Discontinuous changes in density around the threshold can be an indication of endogenous sorting around this threshold, which would violate the RD assumptions (McCrary, 2008). We see no evidence of such changes at either threshold.

Columns 1-4 of Table 3 present regressions of fiscal, housing, and academic variables measured in the year before a bond is proposed on the election outcome, with various controls. The first column includes only year effects and an indicator for a 55\% threshold. It reveals large pre-measure differences in several outcomes. The second column adds a cubic polynomial in the measure vote share. This addition eliminates most of the significant estimates, shrinking the point estimates substantially.

The specifications in Columns 1-2 are estimated from a sample that includes only observations from the year before the election. Columns 3-4 switch to our "static RD" sample, 
pooling observations from two years before through six years after the election. We generalize equation (7) by freeing up the $\gamma_{-1}$ coefficient, the "effect" of bond passage in the year before the election, and report only that coefficient in the table. Column 3 reports the static specification without measure fixed effects, while column 4 includes them. Pooling the data does not substantially change the estimates. The fixed effects specification in Column 4 , however, has much smaller (in absolute value) point estimates and standard errors, particularly in the housing and test score specifications. The fixed effects evidently absorb much of the variation in outcomes that are not related to bond election vote shares.

Columns 5-7 in Table 3 repeat our three first specifications, taking as the dependent variable the change in each outcome between year $t-1$ and $t$. Although the model without controls shows some differences in trends between districts that pass and fail measures, these are eliminated when we include controls for the vote share. Overall, there seems to be little cause for concern about the approximate randomness of the measure passage indicator in our RD framework. Once we control for a cubic in the measure vote share, measure passage does not appear to be correlated with pre-treatment trends of any of the outcomes we examine. ${ }^{29}$

\section{B. School Bond Dynamics}

As noted earlier, school districts where a measure fails are more likely to have proposed and passed a subsequent measure than are districts where the initial measure passes. This pattern is particularly pronounced when the initial vote is close. Figure 2 shows the number of additional measures considered (left panel) and approved (right panel) over the four years following an election. We show averages outcomes for two-percentage-point bins defined by the vote share relative to the threshold. There is a clear discontinuity at measure passage. Passing an initial measure reduces the number of future elections by nearly 1 , on average, and reduces the number that pass by about 0.6. Figure 3 offers another view, plotting estimates from our static RD specification of the effect of measure passage on the cumulative number of measures passed between $t_{0}$ and $t$. Most of the effect is concentrated in the first four years; by this point, the difference in the total number of measures passed between near-passers and near-failures in the initial election has fallen to approximately 0.4 .

\footnotetext{
${ }^{29}$ We also applied similar tests to other covariates, such as sales volume, housing characteristics, and income of homebuyers. We found no evidence of "effects" on any of these.
} 


\section{Results}

\section{A. School District Spending and Flypaper Effects}

We begin our investigation of the effects of measure passage by examining fiscal outcomes. Figures 4, 5, and 6 present graphical analyses of long term debt, capital outlays and current spending by margin of victory or defeat, respectively. As in Figure 2, we show average outcomes in two-percentage-point bins defined by the vote share relative to the threshold. These are computed separately for the year prior to the election and for the third year after the election, and we control for calendar year effects. ${ }^{30}$ For example, the leftmost point shows the average outcome for measures that lost by between 8 and 10 percentage points.

There is no sign of a discontinuity in the debt or capital spending measures in the year before the election. By contrast, three years later, districts where the measure just passed have about $\$ 3,000$ more debt per pupil than districts where the measure narrowly failed, and spend about $\$ 1,000$ more per pupil on capital outlays. There is no evidence whatsoever of a similar discontinuity in current spending, before or after the election.

Table 4 presents estimates of our static RD specification for several fiscal measures. As one would expect, the passage of a school bond measure results in an immediate, substantial increase in a school district's total debt per pupil (Column 1), amounting to about $\$ 1,900$ per pupil in the first year and $\$ 2,300$ in the second. The effect declines quickly thereafter. Columns 2,3 , and 4 present estimates for total district expenditures per pupil, capital outlays per pupil, and current instructional expenditures per pupil. ${ }^{31}$ Bond passage has no significant effect on any of these in the first year. In years 2, 3, and 4, passage causes large increases in total expenditures and capital expenditures; these then die away by year 5 . There is no indication of any effect on current spending in any year, and confidence intervals rule out effects amounting to anything larger than $\$ 100$ per pupil in every year. This is dramatic evidence for flypaper effects-bond revenues appear to "stick" entirely in the capital account. Column 5 presents estimates of the effect of bond passage on state aid. These demonstrate another form of flypaper effect: there is

\footnotetext{
${ }^{30}$ The bin corresponding to measures that failed by less than 2 percentage points is the category excluded from the regression, so estimates may be interpreted as differences relative to that bin. Results are robust to exclusion of the year controls.

${ }^{31}$ Total expenditures equal the sum of capital outlays, current instructional expenditures, current non-instructional expenditures, and debt service payments. We examine non-instructional spending below. Bond passage has a positive mechanical effect on debt service payments. See Appendix Table 1.
} 
no indication that bond revenues crowd out state funding, and indeed all of the point estimates are positive.

Table 5 reports estimates of our dynamic RD specification for all fiscal variables, with district fixed effects and pre-election effects constrained to zero. Column 1 shows that effects on debt grow through year 3, when they reach $\$ 3,400$, and stay roughly constant thereafter. Columns 2 and 3 show that the bond revenues are spent primarily in years 2-5 after passage.

Figure 7 presents estimates from both our static and dynamic specifications for capital spending, showing the latter all the way out to the $18^{\text {th }}$ year after the election (the last that we can estimate). The two specifications yield nearly identical effects in the first two years. As discussed above, the dynamic response of bond proposals to earlier bond outcomes implies that the static framework will understate the effect of bond passage at longer lags. Indeed, the dynamic specification yields much larger effects in years three through six. Sizeable positive effects persist until year eight, then disappear. Appendix Figure 1 shows results from an alternative specification that excludes the district fixed effects and allows for effects before the date of the election. There is no sign of any effect outside of the zero to eight range.

Columns 4 and 5 of Table 7 show results for current spending and state aid. In each year, we can reject effects as small as $\$ 100$ on current spending and there is no evidence of diversions of state aid. The cumulative change in total expenditures in Column 2 is larger than the change in district debt in Column 1. It appears that districts are not using all of their newly-approved authority to issue bonds, and instead are spending some of the additional property tax revenues that derive from the passage of the bond measure directly on capital projects rather than on debt service. Appendix Table 1 presents estimates for a variety of balance sheet measures; results are consistent with this story.

Table 6 presents a variety of alternative specifications meant to probe the robustness of our fiscal results. We focus on the estimates of the dynamic specification; to conserve space we report only the estimated effect of measure passage in relative year 4 after the election. Column 1 reports the baseline specification. Columns 2-4 vary the controls for the election vote share: Column 2 includes only a linear control; Column 3 allows for three linear segments, with kinks at 55\% and $67 \%$ vote shares; and Column 4 allows separate cubic vote share-outcome relationships each of the $[0,55 \%],[55 \%, 67 \%]$, and $[67 \%, 100 \%]$ ranges. None of these change the results appreciably, and in particular none shows evidence of diversion of resources. 
Columns 5-7 report estimated discontinuities at locations other than the threshold required for passage; in each of these specifications, we also allow a discontinuity at the actual threshold. In column 5, we estimate the discontinuity in our outcomes at the counterfactual threshold, $55 \%$ when $v^{*}=2 / 3$ and $2 / 3$ when $v^{*}=55 \%$. We find no discontinuities at this threshold, suggesting that any discontinuities seen in our main specifications reflect true effects of bond passage. Similarly, Columns 6 and 7 show estimates for placebo thresholds 10 percentage points above or below the true threshold. Only one of the coefficients in these columns is significant.

Finally, the last two columns of Table 6 examine whether our evidence for a flypaper effect arises because districts are at corner solutions with respect to capital spending. We divide our sample by the district's capital spending per pupil in the year before the election, distinguishing between districts with above- and below-median (\$562 per pupil) spending. We estimate our static specification separately for each subsample, and report the coefficients for relative year 4 . There is little sign of differences between the two subsamples; the funds stick in the capital account even in districts that appear to have flexibility to divert funds to the current account.

\section{B. Housing Prices}

Figure 8 provides a graphical analysis of the impact of bond passage on housing prices corresponding to the analyses of fiscal outcomes in Figures 2-4. Two important patterns emerge. First, housing prices are positively correlated to vote shares, indicating that higher priced districts are more likely to pass bond measures with larger margins of victory. Second, on the right side of the threshold, in districts where bond measures were approved, housing prices appear to shift upward by 6 or 7 percentage points by the third year after the election.

Table 7 presents static and dynamic specifications for housing prices. We use two measures: the average transaction price during the year and its log. Recall that our housing price specification includes controls for the average characteristics of transacted homes; because we also include district or measure fixed effects, the coefficients on these variables are identified from within-district, over-time changes in the value of housing transactions, and their inclusion should help to ameliorate bias coming from differences in the types of homes transacted.

Columns 1 and 2 present estimates from our static RD specification. Housing prices increase by approximately $\$ 12,000$ within one year of a bond passage, corresponding to a $2.1 \%$ 
increase in log prices. The estimated effects rise slightly thereafter, reaching $\$ 19,000$ and 5.8\% three years after the election, and fading somewhat thereafter. Standard errors are somewhat large, however, and not all of the estimates are statistically significant. Columns 3 and 4 show estimates from our dynamic model. Although standard errors are again high, housing prices increase by $3 \%$ in the year of election and 3.6\% one year later. Effects again rise for the next few years, reaching their peaks in year 5 ( $\$ 28,167$ for price levels) and 6 (6.7\% for logs). Figure 9 reports the coefficients and confidence intervals from Columns 2 and 4 of Table 7, extending the latter series out to year 15. Estimates become extremely imprecise beyond this point, as only the earliest measures are used to identify the effect. There is little fade out in this longer window - even 12 years after measure passage, we see about a $6 \%$ effect on housing prices.

Table 8 reports robustness checks for the housing price estimates, using the same strategies as in Table 6; we focus on effects at a 5 year lag, when Table 7 indicates that the house price effect is largest. The significance of the effects is somewhat sensitive to the functional form of the vote share control (Columns 2-4), but this reflects increasing standard errors more than shrinking point estimates. Indeed, the coefficient estimates are larger in Column 4 than in our main specification. Columns 5, 6, and 7 present estimates for the three placebo thresholds. Here, we see some evidence of a negative discontinuity at the counterfactual threshold (Column 5), but none at the other two. Point estimates of placebo thresholds for other relative years (not shown in the table) do not show any systematic effects.

As noted in Section 2, districts can impose parcel taxes that generate unrestricted revenues, though these are relatively rare. Parcel taxes may be substitutes for bonds, potentially confounding the effect of bond passage. To examine this, we generalize our dynamic RD specification, adding indicators for the presence of a parcel tax measure in relative year $\tau$ and for its passage. ${ }^{32}$ Columns 8 and 9 report the measure passage coefficients for bonds and parcel taxes. The estimated effects of bond measures are unchanged, while parcel tax measures have imprecise effects that cannot be distinguished from zero or from the bond coefficients.

\section{Willingness to Pay for School Facility Investments}

It is instructive to compare the magnitude of our spending and house price effects. In close elections (those with margins of victory or defeat less than two percentage points), the proposed bond averages $\$ 6,309$ per pupil. The average house in these districts is worth

\footnotetext{
${ }^{32} \mathrm{We}$ constrain the vote share polynomial to be the same for the two types of measures.
} 
$\$ 236,433$, so our estimated 3.0\% effect on house prices in the year of the election raises the value of the average house by $\$ 7,136$, and the $6.2 \%$ effect in year 3 corresponds to $\$ 14,633$.

Converting these price changes to estimates of the willingness-to-pay for school spending requires assumptions about bond interest rates, consumers' discount rates, and the speed with which new facilities are brought into service. Under a range of assumptions, we obtain estimates of the marginal WTP for $\$ 1$ per pupil in school facilities spending of approximately $\$ 1.50$ for homeowners who moved to the district in the year following a bond passage, and around $\$ 2$ for homeowners who moved in three to four years later. ${ }^{33}$

Previous estimates of capitalization focus on price responses to permanent increases in annual spending. Comparison of our results to these requires us to convert the one-time expenditures financed by bonds to an equivalent annual flow. We calculate a range of $\$ 330$ to $\$ 460$ for this annuity, using discount rates of 5.24\% and 7.33\%, respectively (Barrow and Rouse, 2004). This implies an elasticity of prices with respect to school spending between 0.43 and 0.61. By comparison, Bradbury, Mayer and Case (2001) and Hilber and Mayer (2004) find an elasticity of 0.23 in Massachusetts, though this rises to 0.57 when they focus on districts where state spending caps are most binding. As California's spending formula is unusually restrictive, the latter is probably a better comparison. Barrow and Rouse (2004) focus on the impact of state aid unaccompanied by tax increases. Their main results, from a national sample, imply elasticities with respect to compensated spending less than one third the size of ours. Again, however, their results are substantially larger when they focus on districts similar to California (in this case, high income and education). Moreover, this comparison is extremely sensitive. If homebuyers assume that changes in state aid formulas will be reversed after ten or twenty years, for example, Barrow and Rouse's implied price response is much closer to ours.

There are, however, important differences between our study and the earlier work. The Bradbury-Mayer-Case, Hilber-Mayer, and Barrow-Rouse studies all examine unrestricted spending. This should produce larger elasticities than does restricted spending. On the other hand, the extremely low levels of capital investment in California may mean that the returns to

\footnotetext{
${ }^{33}$ We discuss the calculation of these figures in Appendix B. Our comparison of home price effects to the per-pupil school revenues is appropriate if the marginal homebuyer has 1 school-aged child. This almost exactly matches the average number of children in owner-occupied California households in the 2000 census who moved in after 1990. The Appendix also discusses tax considerations. Allowing for the deductibility of property taxes and mortgage interest from income taxes lowers the implied WTP, but this is largely offset by the higher tax price borne by recent movers in California. The net effect is to reduce the WTP estimates by about $20 \%$, leaving them still well above $\$ 1$.
} 
spending are considerably higher there than in other states. ${ }^{34}$ Finally, differences in estimates may derive in part from differences in research designs; we are the first in this literature to employ a regression discontinuity framework. Overall, we interpret our capitalization estimates as somewhat large but well within the range of plausible effect sizes implied by earlier work.

Since new homebuyers are willing to pay much more in house prices and property taxes than the total new school investments per house, why do bond referenda ever fail? It is important to stress that house price effects reflect the preferences of the marginal homebuyer. As discussed in Section III, many voters make their decisions on the basis of their personal valuations rather than the anticipated effect on home prices, and many residents may have lower valuations than does the marginal homebuyer. Moreover, our estimates are local to districts where measures barely pass, typically with a $2 / 3$ vote. The returns to investment in these districts may be higher than those elsewhere, and in particular the many districts that have never considered a bond measure may have much lower returns.

\section{Academic Achievement}

Passage of a bond measure appears to lead to large increases in a school district's capital spending, no change in current spending, and substantial house price appreciation. Taken together, these results reveal that improvements in school facilities yield outputs that homebuyers value. These outputs may include academic achievement.

Table 9 reports estimates of the effect of bond passage on third grade reading and math scores. The effects are small and insignificant for the first several years. This result is expected given the time it takes to execute capital projects; the flow of services should not begin for several years. However, the point estimates are generally positive and seem to gradually trend upward. This pattern becomes clear in Figure 10, which plots the point estimates and confidence intervals from the math score specifications. By year six, we see large, significant effects, corresponding to about one sixth of a school-level standard deviation. In terms of the more familiar student-level standard deviations, these correspond to effects of roughly 0.067 for reading and 0.077 for math. ${ }^{35}$

\footnotetext{
${ }^{34}$ Another potentially important difference is the structure of bond measures. Districts are required to announce the projects that will be undertaken before placing the measure on the ballot. This may impose some accountability for the use of the funds, limiting managers' ability to divert the funds toward unproductive purposes. This would imply higher capitalization rates than for less-carefully-targeted funds.

${ }^{35}$ We use the ratio of school-level to student-level standard deviations on the 2007 California Standards Tests (CST) to convert school-level to student-level SDs.
} 
Given the noisiness of the test score data we view these results as merely suggestive: beyond year six, confidence intervals become quite large and the point estimates are not consistently positive. ${ }^{36}$ Nevertheless, they are striking, particularly given that the spending in question is restricted to the capital account. Our findings suggest that the improvements to existing facilities elicited by bond passage, such as repairs to broken windows or the replacement of portable classrooms, may raise achievement by about one third as much as a reduction in class sizes from 22 to 15 students (Krueger 1999, 2003). ${ }^{37}$

Even a maximal interpretation of our test score results, however, cannot account for the full house price effects seen earlier. Previous research on school quality capitalization (see Bayer, Ferreira and McMillan (2007), Black (1999), and Kane, Riegg, and Staiger (2006)) has found that a one school-level standard deviation increase in test scores raises housing prices between four and six percent. This implies that our estimated year-6 effect on test scores would produce a housing price increase just over one percent. ${ }^{38}$

The majority of the estimated three to six percent effect on housing prices (Table 7) must be attributable to non-academic school outputs. These may be particularly important in the case of school facilities improvements. Parents may value new playgrounds or athletic facilities for the recreational opportunities they provide; enhanced safety from a remodeled entrance or dropoff area; and improved child health from asbestos abatement and the replacement of drafty temporary classrooms, even if these do not contribute to academic achievement. New facilities may also be physically appealing, perhaps enhancing the desirability of the neighborhood. Any improvements in these unobservable dimensions of school output will lead to housing price effects that exceed those reflected in student achievement measures. The potential relevance of these channels underscores the importance of using housing markets — rather than simply test scores gains - to value school investments.

\footnotetext{
${ }^{36}$ Due to missing data, the sample size drops significantly after year 6 . Only $58 \%$ of districts remain in our sample seven years after a bond election.

${ }^{37}$ We find no evidence that bond passage affects teacher-pupil ratios, nor that the results could be attributable to the construction of new, smaller schools. Results available upon request.

${ }^{38}$ An increase of .185 of a school-level standard deviation in test scores multiplied by an effect of 6 percentage points would yield a price increase of just 1.1 percentage point. This calculation may understate the achievement effect somewhat, as test scores effects may continue to grow beyond the six year window in which we are able to reliably estimate them. (Note that the last year of our estimates corresponds to the cohort of $3^{\text {rd }}$ graders who entered school in the $3^{\text {rd }}$ year after measure passage, before the capital projects were likely complete.)
} 


\section{F. Household Sorting}

The recent empirical literature on the capitalization of school quality emphasizes the importance of social multiplier effects deriving from preferences for wealthy neighbors (see, e.g., Bayer, Ferreira and McMillan, 2004). If wealthy families have higher willingness-to-pay for school output than do poor families, passage of a bond may lead to increases in the income of inmigrants to the district, creating follow-on increases in the desirability of the district, in house prices, and in test scores.

In Panel A of Table 10 we report dynamic RD estimates for the impact of bond approval on sales volumes. Volumes would be expected to rise if passage leads to changes in the sort of families that prefer the school district. The estimates show that sales volumes increase by 200300 units per year. An analysis of log volumes indicates about a 3\% increase in sales, though this is not statistically significant. ${ }^{39}$

The remainder of Table 10 examines data on the composition of families directly. In Panel B, we find no distinguishable effect on the incomes of new homebuyers or on the racial make-up of these new residents as measured by the share that are white and Asian. ${ }^{40}$ Panel C reports measures describing school district enrollment. We present estimates for the whole district as well as for Kindergarteners and $1^{\text {st }}$ graders; to the extent that families are unwilling to move once their children begin school, effects on sorting may be concentrated in early grades. We find no effect on total enrollment in early grades.

We similarly find no impact on average parental education (available only for the full district population) or on overall racial make-up. We do, however, find a small increase in the fraction of white and Asian students in Kindergarten. Interestingly, this effect is absent (or at the least dramatically smaller) in first grade. ${ }^{41}$ Since bond revenue is frequently used to extend Kindergarten programs from half- to full-day (DiMassa 2003), one potential explanation is that some families switched from private Kindergartens to public schools after bond passage. While

\footnotetext{
${ }^{39}$ Sales volume could also represent an increase in the local supply of homes, but we are unable to disentangle supply and demand effects because yearly data on housing supply is not available. However, we test whether bond passage leads to a change in the composition of houses by estimating our dynamic RD model for housing features such as square footage and lot size. No composition effects are observed.

${ }^{40}$ One caveat is that income is self-reported, from the HMDA data. To the extent that lower income homeowners tend to over report their true incomes, this would bias our estimates towards zero. As explained in the data section, we are also unable to distinguish between intra- and inter-district moves.

${ }^{41}$ We have also estimated results for disaggregated racial groups. Asian (and, to a much lesser extent, white) Kindergarten enrollment rises, while Hispanic enrollment falls.
} 
there is some state-level evidence that private Kindergarten enrollment declined in the past decade relative to enrollment in private elementary and secondary grades, this potential reaction is unlikely to explain more than a very small fraction of the housing price effect. ${ }^{42}$

Since we observe a limited set of characteristics of new movers, it could be that sorting effects are concentrated in other dimensions, such as parental education or the presence of children. Even so, sorting is not likely to account for our full price effect. The literature indicates that social multiplier effects on house prices could be as large as $75 \%$ of the direct effect of school quality (Bayer, Ferreira and McMillan, 2004). This would indicate that at most 2.5 percentage points of the estimated $6 \%$ price effect in year 3 could be due to sorting, still leaving a large portion that must be attributable to increased school output.

\section{Conclusion}

In this paper we develop a "dynamic" regression discontinuity design to estimate the value of school facilities to parents and homeowners. Drawing on the unique characteristics of California's system of school finance, we identify the effects of capital investments on housing prices by comparing districts in which school bond referenda passed or failed by narrow margins. Unlike districts where bond referenda garnered overwhelming voter support or opposition, the set of districts with close votes are likely to be similar to each other in both observable and unobservable characteristics. The analysis is complicated by the tendency for districts in which proposed bonds are rejected to propose and pass additional measures in future years. Our dynamic RD specification accounts for these feedback effects, bringing the identification power of a traditional RD design into a panel data context.

We first examine the impact of passing a bond proposal on school spending. We find sharp and sizable flypaper effects. Bond approval increases capital outlays, and there is no sign that any funds are diverted toward current spending. This is surprising: the inclusion of repairs and maintenance on the list of allowed bond-funded projects would seem to provide ample room for districts to divert previously unrestricted funds, but this appears not to happen. It is possible

\footnotetext{
${ }^{42}$ State level data on private school enrollment is based on Private School Affidavits summarized on the California Department of Education's Ed-Data website. The average cost of a private full-day elementary school program in California was roughly $\$ 3,000$ in 1999 (U.S. Department of Education 2007).
} 
that the requirement to announce capital projects in advance makes it difficult to divert funds toward non-capital uses.

This flypaper result implies that our subsequent analyses can be interpreted as revealing the effects of school facilities. We find that passing a measure causes home prices to rise by about six percent. As theory predicts, most of this effect appears well in advance of the completion of the funded projects. We also find some evidence of effects on student achievement several years after bond passage, but very little effect on the income and racial composition of the school district. The home price effects presumably reflect the anticipation of increased school output, though it seems likely that much of the effect derives from dimensions of output (such as safety) that are not picked up by test scores.

Our results provide clear evidence that the districts that we study are spending well below the economically efficient level. It is worth emphasizing that our results are identified from districts at the margin of passing a bond. Evidently, the referendum process erects too large a barrier to the issuance of bonds and prevents many worthwhile bond issues. A loosening of California's constraints on local spending would yield substantial economic benefits. Our results may have similar implications for other states and localities with low levels of capital investment and highly centralized systems of school finance. 


\section{References}

Ardon, Kenneth, Eric Brunner, and Jon Sonstelie (2000), "For Better or For Worse? School Finance Reform in California," Public Policy Institute of California: San Francisco.

Balsdon, Ed, Eric J. Brunner, and Kim Rueben (2003), "Private Demands for Public Capital: Evidence from School Bond Referenda," Journal of Urban Economics 54(3), p.610-638.

Barrow, Lisa, and Cecilia Rouse (2004), "Using Market Valuation to Assess Public School Spending," Journal of Public Economics 88, p.1747-1769.

Bayer, Patrick, Fernando Ferreira, and Robert McMillan (2004), "Tiebout Sorting, Social Multipliers, and the Demand for School Quality," NBER Working Paper \#10871.

Bayer, Patrick, Fernando Ferreira, and Robert McMillan (2007), “A Unified Framework for Measuring Preferences for Schools and Neighborhoods," The Journal of Political Economy 115(4), p.588-638.

Benabou, Roland (1993), "The Workings of a City: Location, Education, and Production," Quarterly Journal of Economics 108(3), p.619-652.

Black, Sandra E. (1999), "Do Better School Matter? Parental Valuation of Elementary Education," Quarterly Journal of Economics 114(2), p.577-599.

Bradbury, Katharine, Christopher Mayer, and Karl Case (2001), "Property Tax Limits, Local Fiscal Behavior, and Property Values: Evidence from Massachusetts under Proposition 2 1/2," Journal of Public Economics 80, p.287-311.

Bradford, David, and Wallace Oates (1971a), "The Analysis of Revenue Sharing in a New Approach to Collective Fiscal Decisions," Quarterly Journal of Economics 85(3), p.416-439.

Bradford, David, and Wallace Oates (1971b), "Towards a Predictive Theory of Intergovernmental Grants," American Economic Review Papers and Proceedings 61(2), p.440-448.

Brueckner, Jan K. (1979), "Property Values, Local Public Expenditure and Economic Efficiency," Journal of Public Economics 11(2), p.223-245.

Brueckner, Jan K. (1982), "A Test for Allocative Efficiency in the Local Public Sector," Journal of Public Economics 19(3), p.311-331.

Brueckner, Jan K. (1983), "Property Value Maximization and Public Sector Efficiency," Journal of Urban Economics 14(1), p.1-15.

Brunner, Eric J., and Kim Rueben (2001), "Financing New School Construction and Modernization: Evidence from California," National Tax Journal 54(3), p.527-539.

Buckley, Jack, Mark Schneider, and Yi Shang (2005), "Fix It and They Might Stay: School Facility Quality and Teacher Retention in Washington, DC," The Teachers College Record 107(5), p.1107-1123.

Card, David, and Alan Krueger (1992), "Does School Quality Matter? Returns to Education and the Characteristics of Public Schools in the United States," Journal of Political Economy 100(1), p.1-40. 
Card, David, and Alan Krueger (1996), "School Resources and Student Outcomes: An Overview of the Literature and New Evidence from North and South Carolina," Journal of Economic Perspectives 10(4), p.31-50.

Cellini, Stephanie Riegg (2007), "Crowded Colleges and College Crowd-Out: The Impact of Public Subsidies on the Two-Year College Market," Manuscript, George Washington University.

Choi, James J., and David Laibson, and Brigitte C. Madrian (2007), "The Flypaper Effect in Individual Investor Asset Allocation," NBER Working Papers \#13656.

Clotfelter, Charles, Helen Ladd, and Jacob Vigdor (2007), “Are Teacher Absences Worth Worrying About in the U.S.?” NBER Working Papers \#13648.

Cook, Thomas, and Donald Campbell (1979), Quasi-experimentation: Design and Analysis Issues for Field Settings. Boston: Houghton Mifflin.

Dee, Thomas S. (2000), "The Capitalization of Education Finance Reforms," The Journal of Law and Economics 43(1), p.185-214.

DiMassa, Cara Mia (2003), "Parents, Schools Are Learning to Like Full-Day Kindergarten," Los Angeles Times, December 29, 2003, p.A-1.

DiNardo, John, and David S. Lee (2004), "Economic Impacts of New Unionization on Private Sector Employers: 1984-2001," Quarterly Journal of Economics 119(4), p.1383-1441.

Duflo, Esther and Christopher Udry (2004), "Intrahousehold Resource Allocation in Cote d'Ivoire: Social Norms, Separate Accounts and Consumption Choices," NBER Working Papers \#10498.

Earthman, Glen I. (2002), School Facility Conditions and Academic Achievement. Los Angeles, CA: UCLA's Institute for Democracy, Education, and Access (IDEA).

Epple, Dennis, Radu Filimon, and Thomas Romer (1984), "Equilibrium among Local Jurisdictions: Toward an Integrated Approach of Voting and Residential Choice," Journal of Public Economics 24, p.281-308.

Epple, Dennis, Radu Filimon, and Thomas Romer (1993), "Existence of Voting and Housing Equilibrium in a System of Communities with Property Taxes," Regional Science and Urban Economics 23, p.585-610.

Ferreira, Fernando (2007), "You Can Take It with You: Proposition 13 Tax Benefits, Residential Mobility, and Willingness to Pay for Housing Amenities," mimeo, The Wharton School, University of Pennsylvania.

Ferreira, Fernando, and Joseph Gyourko (2009), "Do Political Parties Matter? Evidence from U.S. Cities," forthcoming, Quarterly Journal of Economics.

Fischel, William (1989), “Did Serrano Cause Proposition 13?” National Tax Journal 42(4), p.465-73.

Gordon, Nora (2004), "Do federal grants boost school spending? Evidence from Title I," Journal of Public Economics 88(9-10), p.1771-1792. 
Hahn, Jinyong, Petra Todd, and Wilbert Van der Klaauw (2001), "Identification and Estimation of Treatment Effects with a Regression Discontinuity Design," Econometrica 69(1), p.201209.

Hanushek, Eric A. (1986), "The Economics of Schooling: Production and Efficiency in Public Schools," Journal of Economic Literature 24(3), p.1141-1177.

Hanushek, Eric A. (1996), "School Resources and Student Performance" In Burtless, Gary, Ed., Does Money Matter? The Effect of School Resources on Student Achievement and Adult Success. Washington, D.C., Brookings Institution, p.43-73.

Hanushek, Eric A. (1997), "Assessing the Effects of School Resources on Student Outcomes: An Update," Educational Evaluation and Policy Analysis 19(2), p.141-164.

Heckman, James, Anne Layne-Farrar, and Petra Todd (1996), "Human Capital Pricing Equations with and Application to Estimating the Effect of School Quality on Earnings," Review of Economics and Statistics 78, p.562-610.

Hilber, Christian, and Christopher Mayer (2004), "School Funding Equalization and Residential Location for the Young and the Elderly," Brookings-Wharton Papers on Urban Affairs, p.107-148.

Hines, James R., and Richard H. Thaler (1995), "The Flypaper Effect," Journal of Economic Perspectives 9(4), p.217-26.

Hoxby, Caroline M. (2001), “All School Finance Equalizations are not Created Equal," Quarterly Journal of Economics 116(4), p.1189-1231.

Imbens, Guido, and Thomas Lemieux (2007), "Regression Discontinuity Designs: A Guide to Practice," NBER Working Papers \#13039.

Jones, John T., and Ron W. Zimmer (2001), "Examining the Impact of Capital on Academic Achievement," Economics of Education Review 20, p.577-588.

Kane, Thomas J., Stephanie K. Riegg, and Douglas O. Staiger (2006), "School Quality, Neighborhoods, and Housing Prices," American Law and Economics Review 8(2), p.183212.

Kaplan, Steven N., and Luigi Zingales (1997), "Do Investment-Cash Flow Sensitivities Provide Useful Measures of Financing Constraints?” Quarterly Journal of Economics 112(1), p.169215.

Knight, Brian (2002), "Endogenous Federal Grants and Crowd-out of State Government Spending: Theory and Evidence from the Federal Highway Aid Program," American Economic Review 92(1), p.71-92.

Krueger, Alan. B. (1999), "Experimental Estimates of Education Production Functions," Quarterly Journal of Economics 114(2), p.497-532.

Krueger, Alan. B. (2003), "Economic Considerations and Class Size," The Economic Journal 113 , p.F34-F63.

Lee, David (2001), "The Electoral Advantage to Incumbency and Voters' Valuation of Politicians' Experience: A Regression Discontinuity Analysis of Elections to the U.S. House," NBER Working Papers \#8441. 
Lee, David (2008), "Randomized Experiments from Non-random Selection in U.S. House Elections," Journal of Econometrics 142(2), p.675-697.

Lee, David S., Enrico Moretti, and Matthew J. Butler (2004), "Do Voters Affect or Elect Policies? Evidence from the U.S. House," The Quarterly Journal of Economics (August), p.807-859.

McCrary, Justin (2008), "Manipulation of the Running Variable in the Regression Discontinuity Design: A Density Test," Journal of Econometrics 142(2), p.698-714.

Mendell, Mark J. and Garvin A. Heath (2004), "Do Indoor Environments in Schools Influence Student Performance? A Critical Review of the Literature." Indoor Air 15(1), p. 27-52.

Nechyba, Thomas J. (1997), "Existence of Equilibrium and Stratification in Local and Hierarchical Tiebout Economies with Property Taxes and Voting," Economic Theory 10, p.277-304.

New York Times (1989), "Births and Immigration Squeeze California Classroom Space,” New York Times, October, 8, 1989.

Oates, Wallace E. (1969), "The Effects of Property Taxes and Local Public Spending on Property Values: An Empirical Study of Tax Capitalization and the Tiebout Hypothesis," Journal of Political Economy 77(6), p.957-71.

Orrick, Herrington \& Sutcliffe, LLP. 2004. School Finance Bulletin. Publication of the Public Finance Department of Orrick, Herrington, and Sutcliffe: San Francisco, CA. http://www.orrick.com/fileupload/259.pdf

Palmon, Oded, and Barton A. Smith (1998), "New Evidence on Property Tax Capitalization," The Journal of Political Economy 106(5), p.1099-1111.

Pettersson-Lidbom, Per (2007), "Does the Size of the Legislature Affect the Size of Government? Evidence from Two Natural Experiments," Manuscript, Department of Economics, Stockholm University.

Pettersson-Lidbom, Per (2008), "Do Parties Matter for Economic Outcomes: A RegressionDiscontinuity Approach," Journal of the European Economic Association, 6(5), p. 10371056.

Rosen, Sherwin (1974), "Hedonic Prices and Implicit Markets: Product Differentiation in Pure Competition," Journal of Political Economy 82(1), p.34-55.

Rothstein, Jesse (2006), "Good Principals or Good Peers: Parental Valuation of School Characteristics, Tiebout Equilibrium, and the Incentive Effects of Competition among Jurisdictions," American Economic Review 96(4), p.1333-1350.

Rothstein, Jesse (2008), "Student Sorting and Bias in Value Added Estimation: Selection on Observables and Unobservables," mimeo, Princeton University.

Schneider, Mark (2002), Do School Facilities Affect Academic Outcomes? National Clearinghouse for Educational Facilities. Washington, DC.

Sebastian, Simone (2006), "Schools Measure Proposed," San Francisco Chronicle, March 8, 2006, p.B-1. 
Shapiro, Perry, and Jon Sonstelie (1982), "Did Proposition 13 Slay Leviathan?" American Economic Review 72(2), p.184-90.

Sonstelie, Jon, Eric Brunner, and Kenneth Ardun (2000), For Better or For Worse? School Finance Reform in California, Public Policy Institute of California: San Francisco.

Starrett, David A. (1981), "Land Value Capitalization in Local Public Finance," The Journal of Political Economy 89(2), p.306-327.

Thistlethwaite, Donald L., and Donald T. Campbell (1960), "Regression-Discontinuity Analysis: An Alternative to the Ex-Post Facto Experiment," Journal of Educational Psychology 51, p.309-317.

Tiebout, Charles (1956), “A Pure Theory of Local Public Expenditures”, Journal of Political Economy 64(5), p.416-424.

Uline, Cynthia and Megan Tschannen-Moran (in press), "The Walls Speak: The Interplay of Quality Facilities, School Climate, and Student Achievement," The Journal of Educational Administration.

U.S. Department of Education, National Center for Education Statistics (NCES), (1998), Digest of Education Statistics 1998. http://nces.ed.gov/programs/digest/d98/index.asp.

U.S. Department of Education, National Center for Education Statistics (NCES), (2007), Digest of Education Statistics 2007. http://nces.ed.gov/programs/digest/d07/index.asp. 


\section{Appendix A}

\section{Resource Allocation with Restricted Funding}

Under fairly general conditions, an optimizing school district given additional restricted revenues will divert some of the additional revenues to other purposes, by reducing the allocation of unrestricted revenues to the targeted accounts. This prediction will fail to hold only if the district was previously at a corner solution, allocating no revenue to the targeted accounts; in this case, there is no possibility of diversion.

A school district receives funding y from federal and state transfers plus local revenues; we treat all as exogenous to local decisions. The district allocates this funding across school facilities (k) and current inputs such as teachers and textbooks (e). Let A measure educational outputs, and suppose that the educational production function is $A=f(k, e)$. If revenues are unrestricted, the district maximizes A subject to the budget constraint $\mathrm{k}+\mathrm{e} \leq \mathrm{y}$. Let $\mathrm{k}(\mathrm{y})$ and $\mathrm{e}(\mathrm{y})$ be the optimal resource choices; these will sum to total revenues, $\mathrm{k}(\mathrm{y})+\mathrm{e}(\mathrm{y})=\mathrm{y}$, and (assuming an interior solution) will equate the marginal product of each type of spending, $\mathrm{f}_{1}(\mathrm{k}(\mathrm{y}), \mathrm{e}(\mathrm{y}))=$ $\mathrm{f}_{2}(\mathrm{k}(\mathrm{y}), \mathrm{e}(\mathrm{y}))$. For typical production functions, both $\mathrm{k}(\mathrm{y})$ and $\mathrm{e}(\mathrm{y})$ will be increasing in $\mathrm{y}$. Thus, a grant of additional unrestricted revenues $r$ will lead to increases in both capital and current spending, $\mathrm{k}(\mathrm{y}+\mathrm{r})>\mathrm{k}(\mathrm{y})$ and $\mathrm{e}(\mathrm{y}+\mathrm{r})>\mathrm{e}(\mathrm{y})$.

Now suppose that the new revenues are restricted to the capital account. One might expect this sort of restricted grant to increase capital revenues by the full amount $r$, to $k(y)+r$. But this is usually not so. The grant restrictions simply add an additional constraint, $\mathrm{k} \geq \mathrm{r}$. This can be satisfied with much smaller increases if $\mathrm{k}(\mathrm{y})>0$. An optimizing district will re-allocate unrestricted revenues toward the current account. That is, rather than choosing $(\mathrm{k}(\mathrm{y})+\mathrm{r}, \mathrm{e}(\mathrm{y}))$, the district will devote only $\mathrm{k}^{*}<\mathrm{k}(\mathrm{y})$ of its unrestricted revenues to the capital account, leading to a total capital allocation of $\mathrm{k}^{*}+\mathrm{r}<\mathrm{k}(\mathrm{y})+\mathrm{r}$ and total current spending of $\mathrm{e}^{*}>\mathrm{e}(\mathrm{y})$.

The degree of diversion will depend on the extent to which the $\mathrm{k} \geq \mathrm{r}$ constraint is binding. In one extreme, it is not binding at all - the district would have chosen capital spending greater than $r$ even without constraints $(k(y+r)>r)$. In this case, the restriction has no effect on the district's allocation decisions. For this sort of district, the passage of a restricted bond is predicted to lead to increases in both capital and current spending identical to those that would be seen with an unrestricted revenue grant.

On the other extreme, a district might, if unconstrained, choose to spend nothing on capital $(\mathrm{k}(\mathrm{y}+\mathrm{r})=0)$. In this case, the restriction is extremely effective: The district cannot devote a negative amount of its unrestricted budget toward the capital account. It instead selects a corner solution, setting $\mathrm{k}^{*}=0$ and $\mathrm{e}^{*}=\mathrm{y}$. This yields total capital spending of $\mathrm{r}$ and total current spending of $y$. The additional revenues thus "stick" entirely in the capital account, with no spillovers to the current account.

Of course, there are intermediate cases. If $\mathrm{k}(\mathrm{y})>0$ but $\mathrm{k}(\mathrm{y}+\mathrm{r})<\mathrm{r}$, a restricted grant will lead to more capital spending than would an unrestricted grant, but less than would occur if the district were unable to re-optimize upon receipt of the grant. 


\section{Appendix B}

\section{Willingness-to-Pay and Elasticity Calculations}

This appendix describes how the reduced-form effects of bond passage on house prices can be converted to obtain estimates of the marginal homebuyer's willingness-to-pay for school spending and of the elasticity of house prices with respect to school spending.

We make a number of assumptions in the calculations. We assume that the (nominal) interest rate on bonds is $4.6 \%$, that a rental unit is equivalent to 0.6 owner-occupied units, and that the tax burden is divided evenly among all of the (owner-equivalent) housing units in the district. We consider a bond issue of $\$ 6,309$ per pupil, with a 30 -year maturity, in a district with average housing price of $\$ 236,433$ and 2.4 owner-equivalent units per pupil. ${ }^{43}$ We consider two discount rates, $7.33 \%$ and $5.24 \%$, both taken from Barrow and Rouse (2004).

The simplest calculation is the willingness-to-pay for additional spending. Under the assumption that marginal homebuyers have exactly one school-aged child per household, we assume that the price effects reflect the willingness-to-pay for a per-pupil share of the average bond. The estimates in Column 4 of Table 7 indicate that bond passage raises prices by $3.02 \%$ in the first year, or $\$ 7,136$ for the average house. With 2.4 homes per pupil, a single home's share of the average bond issue is $\$ 2,629$. This requires annual property taxes of $\$ 163$, with present discounted value of $\$ 1,952\left(\rho_{1}=7.33 \%\right)$ or $\$ 2,431\left(\rho_{2}=5.24 \%\right)$. Thus, the willingness to pay for $\$ 6,309$ per pupil in bond funds is $\$ 7,136+\$ 1,952=\$ 9,087\left(\rho_{1}\right)$ or $\$ 7,136+\$ 2,431=\$ 9,567$ $\left(\rho_{2}\right)$, implying a willingness-to-pay for $\$ 1$ per pupil in spending of 1.44 or 1.52 , respectively.

Table 7 indicates that the price effects are larger a few years after the election than in the first year. By this point, some of the taxes will already have been paid, but (assuming that planning and executing a construction project takes several years) none of the benefits will have been received. Moreover, because the arrival of benefits is approaching, these benefits will be discounted to a lesser degree. Thus, a constant willingness-to-pay would imply slowly rising price effects over this period, though cannot account for the steep rate of increase. Our estimate of the willingness-to-pay is 1.63 in year $2,2.12$ in year 3 , and 1.70 in year 4 (for $\rho_{1} ; \rho_{2}$ implies $1.76,2.31$, and 1.89 , respectively). It is not possible to extend these estimates beyond year 4 , as the assumption that all of the benefits arrive after that date is untenable.

The calculations thus far omit two tax considerations. First, because California freezes valuations at the original purchase price, new homebuyers pay a disproportionate share of property taxes. Using Ferreira's (2007) tabulation of effective property tax rates in California, we compute that property tax increment that raises $\$ 1$ per house will cost a new homebuyer about $\$ 1.35$ and a long-term resident only about $\$ 0.58$. This implies that the above calculations understate the tax burden borne by new buyers. Offsetting this, however, is the income tax deductibility of property tax payments and mortgage interest payments. When we incorporate both of these features into the calculation, our year-4 price estimates imply that marginal

\footnotetext{
${ }^{43}$ The bond amount and housing price are the means among districts with measures that pass or fail by less than $2 \%$. The equivalence of a rental unit with 0.6 owner-occupied units is computed by comparing the present discounted value of the California mean monthly rent for a renter-occupied unit in 2000 (using a 5.24\% discount rate) with the mean value of owner occupied homes. The count of housing units per pupil is the average in our sample; the average for districts with close elections is similar. Note also that the $\$ 6,309$ per pupil of the average bond is quite close to the present discounted value of our point estimates of the effect of bond passage on total spending in years $1-18, \$ 5,672(\rho=7.33 \%)$ or $\$ 6,086(\rho=5.24 \%)$.
} 
homebuyers are willing to give up $\$ 1.35\left(\rho_{1}\right)$ or $\$ 1.51\left(\rho_{2}\right)$ worth of consumption in order to provide $\$ 1$ per pupil to the school district's capital budget. ${ }^{44}$

Other studies of the home price effects of school spending do not report the implied willingness-to-pay for spending. To estimate the elasticity of housing prices with respect to annual school spending, as reported by Bradbury, Mayer, and Case (2001) and Hilber and Mayer (2004), we first compute the size of the annuity that yields the same discounted value as the temporary spending increase made possible by the bonds. This is $\$ 462\left(\rho_{1}\right)$ or $\$ 330\left(\rho_{2}\right)$. Next, we divide this by annual per pupil spending (in the year of the election, averaged over all districts where a measure passed or failed by less than two percentage points), $\$ 6,767$. The bond measures therefore represent an increase in the flow of spending of $6.8 \%\left(\rho_{1}\right)$ or $4.9 \%\left(\rho_{2}\right)$. Comparing these to the housing price effects from Table 7, Column 4, we obtain elasticities of year- 0 prices with respect to spending of 0.44 or 0.61 , respectively. Elasticities of year- 4 prices are 0.68 and 1.03 , again depending on the discount rate.

Barrow and Rouse (2004) estimate the effect of state aid - which they interpret as free transfers - on aggregate home prices, both measured in per pupil terms. To adapt our results to a similar metric, we first convert our effects on house prices to effects on property values per pupil. The estimates from Table 7, Column 4 indicate price effects of $\$ 7,136$ in year 0 and $\$ 12,348$ in year 4 . Multiplying this by 2.4 housing units per pupil, we find effects of $\$ 17,126$ in year 0 and $\$ 29,635$ in year 4 . Comparing these to the average bond value, $\$ 6,309$, we estimate that school spending with present discounted value of $\$ 1$ per pupil raises aggregate property values by $\$ 2.71$ in year 0 and $\$ 4.70$ in year 4 .

Barrow and Rouse's (2004) estimates represent the effect of free transfers, while the bond spending studied here must be paid for by increased property taxes. To compute the effect of tax-financed spending implied by Barrow and Rouse's estimates, we first note that they compare their results to the null hypothesis that prices rise by $\$ 1$ per dollar of present discounted value of future state aid. The ratio of their estimates to the null, less one, can therefore be interpreted as the effect of $\$ 1$ of state aid to be paid for with $\$ 1$ in taxes (both in present value). Their main specification yields an estimated coefficient of 30.285; this corresponds to a housing price effect per dollar of bonds of 0.16 (with a discount rate of 5.24\%) to 0.63 (with a discount rate of $7.3 \%$ ).

While these estimates are lower than our findings, several further considerations help reconcile these results. First, Barrow and Rouse find much greater capitalization in bettereducated and higher-income districts. To the extent that California's education and income levels are higher than the national average, we would expect Barrow and Rouse's estimate for all districts to underestimate the housing price effect for the state. Barrow and Rouse's estimates for the top $80 \%$ of districts by education (as measured by the share of the population without a high school diploma) yield a range of $0.42-0.99$, while their estimates for the top quintile of districts by average household income yield 2.52-3.93. Further, the interpretation of their results is quite sensitive to the discount rate: using a $10 \%$ discount rate, their estimates of the effect on property values range from 1.1 for all districts to 5.7 for the top quintile. Finally, Barrow and Rouse's estimates reflect the value of a permanent increase in state aid, while homebuyers might be uncertain about the permanency of the policy changes they examine. If the stream of state aid is expected to persist for only 20 years, the implied effect on property values per dollar of future spending is much larger. Thus, our estimates are not out of line with theirs.

\footnotetext{
${ }^{44} \mathrm{We}$ assume that the owners of the transacted homes will average $130 \%$ of the per-house tax burden, that the new buyers finance $80 \%$ of the increment to home prices associated with a bond using a 30 -year mortgage with a fixed $8 \%$ interest rate, and that they face a marginal income tax rate of $32 \%$.
} 
Table 1. School bond measure summary statistics

\begin{tabular}{|c|c|c|c|c|c|c|}
\hline \multirow[b]{2}{*}{ Year } & \multirow{2}{*}{$\begin{array}{c}\text { Number of } \\
\text { measures } \\
(1)\end{array}$} & \multirow{2}{*}{$\begin{array}{c}\text { Avg \$ PP } \\
\text { year-2000 \$ } \\
(2)\end{array}$} & \multirow{2}{*}{$\begin{array}{c}\text { Fraction } \\
55 \% \text { req. } \\
(3)\end{array}$} & \multirow{2}{*}{$\begin{array}{c}\text { Fraction } \\
\text { approved } \\
(4)\end{array}$} & \multicolumn{2}{|c|}{ Vote share in favor } \\
\hline & & & & & $\begin{array}{c}\text { Mean } \\
(5)\end{array}$ & $\begin{array}{l}\text { SD } \\
(6) \\
\end{array}$ \\
\hline 1987 & 29 & 3,134 & 0 & 0.52 & 64.61 & 11.96 \\
\hline 1988 & 33 & 5,081 & 0 & 0.61 & 67.84 & 8.21 \\
\hline 1989 & 28 & 3,103 & 0 & 0.50 & 66.39 & 9.67 \\
\hline 1990 & 31 & 7,096 & 0 & 0.42 & 61.35 & 15.17 \\
\hline 1991 & 55 & 7,612 & 0 & 0.40 & 64.04 & 10.32 \\
\hline 1992 & 57 & 7,467 & 0 & 0.40 & 62.16 & 10.79 \\
\hline 1993 & 45 & 7,305 & 0 & 0.47 & 62.07 & 11.68 \\
\hline 1994 & 50 & 7,365 & 0 & 0.42 & 65.11 & 9.62 \\
\hline 1995 & 84 & 6,266 & 0 & 0.48 & 65.03 & 10.94 \\
\hline 1996 & 50 & 5,780 & 0 & 0.70 & 70.26 & 7.94 \\
\hline 1997 & 110 & 7,244 & 0 & 0.64 & 68.86 & 8.68 \\
\hline 1998 & 116 & 6,762 & 0 & 0.60 & 68.74 & 9.30 \\
\hline 1999 & 82 & 9,425 & 0 & 0.62 & 69.59 & 9.73 \\
\hline 2000 & 86 & 6,307 & 0 & 0.65 & 69.44 & 8.72 \\
\hline 2001 & 50 & 8,338 & 0.48 & 0.84 & 68.65 & 9.24 \\
\hline 2002 & 146 & 6,004 & 0.89 & 0.79 & 63.44 & 8.50 \\
\hline 2003 & 18 & 6,542 & 0.50 & 0.56 & 61.58 & 9.59 \\
\hline 2004 & 106 & 8,130 & 0.93 & 0.82 & 65.15 & 8.62 \\
\hline 2005 & 35 & 10,157 & 0.74 & 0.86 & 64.70 & 6.53 \\
\hline 2006 & 109 & 9,748 & 0.96 & 0.72 & 60.97 & 7.88 \\
\hline
\end{tabular}


Table 2. School district descriptive statistics for fiscal, housing markets and academic variables

\begin{tabular}{|c|c|c|c|c|c|c|}
\hline & $\begin{array}{l}\text { All school } \\
\text { disricts }\end{array}$ & $\begin{array}{c}\text { Never } \\
\text { proposed a } \\
\text { measure }\end{array}$ & $\begin{array}{c}\text { Proposed at } \\
\text { least one } \\
\text { measure }\end{array}$ & $\begin{array}{l}\text { Passed a } \\
\text { measure } \\
\text { (time t-1) } \\
\end{array}$ & $\begin{array}{c}\text { Failed a } \\
\text { measure } \\
\text { (time t-1) }\end{array}$ & $\begin{array}{c}\text { Diff }(4)-(5) \\
\text { (t stat) }\end{array}$ \\
\hline & $(1)$ & $(2)$ & (3) & $(4)$ & (5) & $(6)$ \\
\hline Number of districts & 948 & 319 & 629 & & & \\
\hline \multicolumn{7}{|l|}{ A. Fiscal variables } \\
\hline Number of observations & 10197 & 3306 & 6891 & 626 & 218 & \\
\hline Log enrollment & $\begin{array}{c}7.43 \\
{[1.69]}\end{array}$ & $\begin{array}{c}6.18 \\
{[1.43]}\end{array}$ & $\begin{array}{c}8.03 \\
{[1.47]}\end{array}$ & $\begin{array}{c}8.34 \\
{[1.48]}\end{array}$ & $\begin{array}{c}8.09 \\
{[1.48]}\end{array}$ & $\begin{array}{c}0.25 \\
(2.13)\end{array}$ \\
\hline Long-term debt PP & $\begin{array}{l}\$ 1,984 \\
{[3,286]}\end{array}$ & $\begin{array}{c}479 \\
{[1,793]}\end{array}$ & $\begin{array}{c}2,706 \\
{[3,581]}\end{array}$ & $\begin{array}{c}1,736 \\
{[3,072]}\end{array}$ & $\begin{array}{c}1,247 \\
{[2,388]}\end{array}$ & $\begin{array}{c}489 \\
(2.41)\end{array}$ \\
\hline \multirow[t]{2}{*}{ Total expenditures PP } & $\$ 7,466$ & 7,410 & 7,493 & 7,290 & 6,941 & 349 \\
\hline & {$[2,177]$} & {$[2,293]$} & {$[2,119]$} & {$[1,898]$} & {$[1,921]$} & $(2.32)$ \\
\hline Total capital outlays PP & $\begin{array}{c}\$ 922 \\
{[1,100]}\end{array}$ & $\begin{array}{c}679 \\
{[905]}\end{array}$ & $\begin{array}{c}1,038 \\
{[1,164]}\end{array}$ & $\begin{array}{c}882 \\
{[1,005]}\end{array}$ & $\begin{array}{c}935 \\
{[1,112]}\end{array}$ & $\begin{array}{c}-53 \\
(0.62)\end{array}$ \\
\hline Total current instr. exp. PP & $\begin{array}{c}\$ 3,905 \\
{[808]}\end{array}$ & $\begin{array}{l}4,034 \\
{[941]}\end{array}$ & $\begin{array}{l}3,844 \\
{[728]}\end{array}$ & $\begin{array}{l}3,824 \\
{[703]}\end{array}$ & $\begin{array}{l}3,618 \\
{[677]}\end{array}$ & $\begin{array}{c}206 \\
(3.82)\end{array}$ \\
\hline $\begin{array}{l}\text { Total current non-instr. } \\
\text { exp. PP }\end{array}$ & $\begin{array}{c}\$ 2,439 \\
{[789]}\end{array}$ & $\begin{array}{l}2,555 \\
{[964]}\end{array}$ & $\begin{array}{l}2,383 \\
{[683]}\end{array}$ & $\begin{array}{l}2,412 \\
{[661]}\end{array}$ & $\begin{array}{l}2,269 \\
{[608]}\end{array}$ & $\begin{array}{c}143 \\
(2.92)\end{array}$ \\
\hline \multicolumn{7}{|l|}{ B. Housing market variables } \\
\hline Number of observations & 15151 & 4578 & 10573 & 731 & 382 & \\
\hline House prices & $\begin{array}{c}241537 \\
{[198,618]}\end{array}$ & $\begin{array}{c}190337 \\
{[149,691]}\end{array}$ & $\begin{array}{c}263706 \\
{[212,612]}\end{array}$ & $\begin{array}{c}285857 \\
{[240,439]}\end{array}$ & $\begin{array}{c}210499 \\
{[178,766]}\end{array}$ & $\begin{array}{c}75,358 \\
(5.91)\end{array}$ \\
\hline Log house prices & $\begin{array}{l}12.16 \\
{[0.65]}\end{array}$ & $\begin{array}{l}11.95 \\
{[0.62]}\end{array}$ & $\begin{array}{l}12.26 \\
{[0.65]}\end{array}$ & $\begin{array}{l}12.33 \\
{[0.66]}\end{array}$ & $\begin{array}{l}12.08 \\
{[0.55]}\end{array}$ & $\begin{array}{c}0.25 \\
(6.71)\end{array}$ \\
\hline Square footage & $\begin{array}{l}1603 \\
{[407]}\end{array}$ & $\begin{array}{l}1572 \\
{[456]}\end{array}$ & $\begin{array}{l}1615 \\
{[386]}\end{array}$ & $\begin{array}{l}1625 \\
{[401]}\end{array}$ & $\begin{array}{l}1637 \\
{[363]}\end{array}$ & $\begin{array}{c}-11 \\
(0.47)\end{array}$ \\
\hline Lot size & $\begin{array}{c}56772 \\
{[81,652]}\end{array}$ & $\begin{array}{c}97604 \\
{[111,614]}\end{array}$ & $\begin{array}{c}39797 \\
{[57,266]}\end{array}$ & $\begin{array}{c}32342 \\
{[48,933]}\end{array}$ & $\begin{array}{c}49388 \\
{[60,891]}\end{array}$ & $\begin{array}{c}\mathbf{- 1 7 , 0 4 7} \\
(4.73)\end{array}$ \\
\hline Sales volume & $\begin{array}{c}881 \\
{[1,966]}\end{array}$ & $\begin{array}{c}316 \\
{[951]}\end{array}$ & $\begin{array}{c}1126 \\
{[2,225]}\end{array}$ & $\begin{array}{c}1519 \\
{[3,568]}\end{array}$ & $\begin{array}{c}1134 \\
{[1,445]}\end{array}$ & $\begin{array}{c}385 \\
(2.54)\end{array}$ \\
\hline Income of homebuyers & $\begin{array}{c}96482 \\
{[59,094]}\end{array}$ & $\begin{array}{c}84753 \\
{[45,204]}\end{array}$ & $\begin{array}{c}101674 \\
{[63,606]}\end{array}$ & $\begin{array}{c}107689 \\
{[70,382]}\end{array}$ & $\begin{array}{c}90339 \\
{[58,903]}\end{array}$ & $\begin{array}{c}17,350 \\
(4.36)\end{array}$ \\
\hline Log income of homebuyers & $\begin{array}{l}11.36 \\
{[0.46]}\end{array}$ & $\begin{array}{l}11.25 \\
{[0.43]}\end{array}$ & $\begin{array}{l}11.40 \\
{[0.47]}\end{array}$ & $\begin{array}{l}11.45 \\
{[0.49]}\end{array}$ & $\begin{array}{l}11.31 \\
{[0.41]}\end{array}$ & $\begin{array}{c}0.14 \\
(5.13)\end{array}$ \\
\hline \multicolumn{7}{|l|}{ C. Achievement variables } \\
\hline Number of observations & 9748 & 3240 & 6508 & 460 & 170 & \\
\hline Reading, grade 3 & $\begin{array}{l}0.172 \\
{[0.91]}\end{array}$ & $\begin{array}{l}0.103 \\
{[0.96]}\end{array}$ & $\begin{array}{l}0.206 \\
{[0.88]}\end{array}$ & $\begin{array}{l}0.159 \\
{[0.93]}\end{array}$ & $\begin{array}{l}0.187 \\
{[0.81]}\end{array}$ & $\begin{array}{r}-0.028 \\
(0.37)\end{array}$ \\
\hline Math, grade 3 & $\begin{array}{l}0.067 \\
{[0.90]}\end{array}$ & $\begin{array}{c}-0.058 \\
{[0.99]}\end{array}$ & $\begin{array}{l}0.129 \\
{[0.85]}\end{array}$ & $\begin{array}{l}0.115 \\
{[0.88]}\end{array}$ & $\begin{array}{l}0.095 \\
{[0.82]}\end{array}$ & $\begin{array}{l}0.020 \\
(0.27)\end{array}$ \\
\hline
\end{tabular}

Notes: Samples in columns 1, 2 and 3 include all available observations in all years. Columns 4 and 5 include only observations for the year prior to a bond measure. Fiscal variables are available for years 1995-2005, housing market variables for 1988 to 2005 (with the exception of income and log income that span the years 1992-2006), and test scores for 1992-1993 and 1997-2006. 
Table 3. Pre-bond measure balance of treatment and control groups

\begin{tabular}{|c|c|c|c|c|c|c|c|}
\hline & \multicolumn{4}{|c|}{ Year before election (t-1) } & \multicolumn{3}{|c|}{ Change, $\mathrm{t}-2$ to $\mathrm{t}-1$} \\
\hline & $(1)$ & $(2)$ & $(3)$ & $(4)$ & $(5)$ & $(6)$ & $(7)$ \\
\hline \multicolumn{8}{|l|}{ A. Fiscal Outcomes } \\
\hline Long term debt PP & $\begin{array}{c}167 \\
(192)\end{array}$ & $\begin{array}{l}-608 \\
(344)\end{array}$ & $\begin{array}{l}-411 \\
(312)\end{array}$ & $\begin{array}{c}79 \\
(165)\end{array}$ & $\begin{array}{l}24 \\
(61)\end{array}$ & $\begin{array}{c}61 \\
(90)\end{array}$ & $\begin{array}{c}86 \\
(86)\end{array}$ \\
\hline Capital outlays PP & -185 & -230 & -163 & -44 & -4 & 46 & 88 \\
\hline & (89) & (139) & (129) & (148) & (89) & $(124)$ & (127) \\
\hline Current instructional exp. PP & $\begin{array}{c}91 \\
(45)\end{array}$ & $\begin{array}{l}-23 \\
(69)\end{array}$ & $\begin{array}{l}-12 \\
(62)\end{array}$ & $\begin{array}{c}35 \\
(36)\end{array}$ & $\begin{array}{c}-7 \\
(19)\end{array}$ & $\begin{array}{c}-5 \\
(29)\end{array}$ & $\begin{array}{c}-1 \\
(31)\end{array}$ \\
\hline \multicolumn{8}{|l|}{ B. Housing market outcomes } \\
\hline House prices & $\begin{array}{l}\mathbf{5 3 0 1 1} \\
(9113)\end{array}$ & $\begin{array}{c}-2243 \\
(13713)\end{array}$ & $\begin{array}{c}643 \\
(13393)\end{array}$ & $\begin{array}{c}3743 \\
(4447)\end{array}$ & $\begin{array}{c}5580 \\
(2260)\end{array}$ & $\begin{array}{c}4631 \\
(4592)\end{array}$ & $\begin{array}{c}4657 \\
(4255)\end{array}$ \\
\hline Log house prices & $\begin{array}{c}0.184 \\
(0.029)\end{array}$ & $\begin{array}{c}0.043 \\
(0.044)\end{array}$ & $\begin{array}{c}0.040 \\
(0.043)\end{array}$ & $\begin{array}{c}0.013 \\
(0.011)\end{array}$ & $\begin{array}{c}\mathbf{0 . 0 1 5} \\
(0.007)\end{array}$ & $\begin{array}{c}0.020 \\
(0.010)\end{array}$ & $\begin{array}{c}0.017 \\
(0.010)\end{array}$ \\
\hline \multicolumn{8}{|l|}{ C. Achievement outcomes } \\
\hline Reading, grade 3 & $\begin{array}{l}-0.040 \\
(0.084)\end{array}$ & $\begin{array}{c}0.147 \\
(0.127)\end{array}$ & $\begin{array}{c}0.185 \\
(0.117)\end{array}$ & $\begin{array}{l}-0.010 \\
(0.054)\end{array}$ & $\begin{array}{l}-0.022 \\
(0.033)\end{array}$ & $\begin{array}{l}-0.032 \\
(0.055)\end{array}$ & $\begin{array}{l}-0.022 \\
(0.057)\end{array}$ \\
\hline Math, grade 3 & $\begin{array}{c}0.042 \\
(0.083)\end{array}$ & $\begin{array}{c}0.180 \\
(0.119)\end{array}$ & $\begin{array}{c}0.214 \\
(0.109)\end{array}$ & $\begin{array}{c}0.054 \\
(0.062)\end{array}$ & $\begin{array}{l}-0.054 \\
(0.037)\end{array}$ & $\begin{array}{l}-0.002 \\
(0.055)\end{array}$ & $\begin{array}{c}0.004 \\
(0.056)\end{array}$ \\
\hline Year effects \& threshold control & Y & $\mathrm{Y}$ & Y & $\mathrm{Y}$ & $\mathrm{Y}$ & $\mathrm{Y}$ & $\mathrm{Y}$ \\
\hline Cubic vote share & $\mathrm{N}$ & $\mathrm{Y}$ & $\mathrm{Y}$ & $\mathrm{Y}$ & $\mathrm{N}$ & $\mathrm{Y}$ & $\mathrm{Y}$ \\
\hline Sample pools relative years $[-2,6]$ & $\mathrm{N}$ & $\mathrm{N}$ & Y & $\mathrm{Y}$ & $\mathrm{N}$ & $\mathrm{N}$ & $\mathrm{Y}$ \\
\hline Bond measure fixed effects & $\mathrm{N}$ & $\mathrm{N}$ & $\mathrm{N}$ & $\mathrm{Y}$ & $\mathrm{N}$ & $\mathrm{N}$ & $\mathrm{N}$ \\
\hline
\end{tabular}

Note: Estimates in columns 1-2 and 5-6 are estimated from cross-sectional data with observations for the year before a measure. Columns 3, 4, and 7 are taken from the static RD model (equation (7)), with only the effect of passage in the year before the election reported. In column 4, the effect two years before the election is constrained to zero. Models for house prices include controls for square footage, lot size and sales volume. Standard errors are robust to heteroskedasticity and, in columns 3, 4, and 7, clustered at the school district level. See text for additional description of samples. 
Table 4. Static RD estimates of effect of bond passage on fiscal variables

\begin{tabular}{|c|c|c|c|c|c|}
\hline & LT debt PP & $\begin{array}{c}\text { Total } \\
\text { expend. PP }\end{array}$ & $\begin{array}{c}\text { Capital } \\
\text { outlays PP }\end{array}$ & $\begin{array}{l}\text { Curr. Instr. } \\
\text { expend. PP }\end{array}$ & $\begin{array}{c}\text { State aid } \\
\text { PP }\end{array}$ \\
\hline & $(1)$ & $(2)$ & $(3)$ & $(4)$ & (5) \\
\hline Effect of measure passage 1 year later & $\begin{array}{l}1932 \\
(360)\end{array}$ & $\begin{array}{c}332 \\
(178)\end{array}$ & $\begin{array}{c}256 \\
(152)\end{array}$ & $\begin{array}{c}35 \\
(39)\end{array}$ & $\begin{array}{c}94 \\
(127)\end{array}$ \\
\hline Effect of measure passage 2 years later & $\begin{array}{l}2290 \\
(439)\end{array}$ & $\begin{array}{c}939 \\
(218)\end{array}$ & $\begin{array}{c}801 \\
(194)\end{array}$ & $\begin{array}{c}9 \\
(43)\end{array}$ & $\begin{array}{c}61 \\
(148)\end{array}$ \\
\hline Effect of measure passage 3 years later & $\begin{array}{l}2210 \\
(473)\end{array}$ & $\begin{array}{l}1274 \\
(277)\end{array}$ & $\begin{array}{l}1144 \\
(250)\end{array}$ & $\begin{array}{c}3 \\
(45)\end{array}$ & $\begin{array}{c}-63 \\
(174)\end{array}$ \\
\hline Effect of measure passage 4 years later & $\begin{array}{l}1607 \\
(574)\end{array}$ & $\begin{array}{c}973 \\
(310)\end{array}$ & $\begin{array}{c}872 \\
(284)\end{array}$ & $\begin{array}{l}-25 \\
(55)\end{array}$ & $\begin{array}{c}94 \\
(171)\end{array}$ \\
\hline Effect of measure passage 5 years later & $\begin{array}{c}908 \\
(613)\end{array}$ & $\begin{array}{c}210 \\
(320)\end{array}$ & $\begin{array}{c}238 \\
(281)\end{array}$ & $\begin{array}{l}-19 \\
(71)\end{array}$ & $\begin{array}{c}166 \\
(167)\end{array}$ \\
\hline Effect of measure passage 6 years later & $\begin{array}{c}367 \\
(660)\end{array}$ & $\begin{array}{l}-326 \\
(338)\end{array}$ & $\begin{array}{l}-351 \\
(284)\end{array}$ & $\begin{array}{l}-19 \\
(74)\end{array}$ & $\begin{array}{c}21 \\
(184)\end{array}$ \\
\hline R2 & 0.77 & 0.73 & 0.47 & 0.90 & 0.77 \\
\hline
\end{tabular}

Notes: "Static" specification is used, following equation (7) in the text. The sample includes relative years [-2, +6$]$ and $\mathrm{N}=6,970$. Coefficients shown are the interaction between relative year indicators and an indicator for bond passage. All specifications include measure fixed effects; a full set of absolute and relative year indicators; and interactions between relative year indicators 1 through $6(0,-1$, and -2 are excluded) and the passage indicator, a cubic in the measure vote share, and a linear measure of the required vote share. Standard errors are clustered on the school district. Dependent variables are measured in constant year-2000 dollars per pupil.

Table 5. Dynamic RD estimates of effect of bond passage on fiscal variables

\begin{tabular}{|c|c|c|c|c|c|}
\hline & LT debt PP & $\begin{array}{c}\text { Total } \\
\text { expend. PP }\end{array}$ & $\begin{array}{c}\text { Capital } \\
\text { outlays PP }\end{array}$ & $\begin{array}{l}\text { Curr. Instr. } \\
\text { expend. PP }\end{array}$ & $\begin{array}{c}\text { State aid } \\
\text { PP }\end{array}$ \\
\hline & (1) & (2) & (3) & (4) & (5) \\
\hline Effect of measure passage 1 year later & $\begin{array}{l}1944 \\
(442)\end{array}$ & $\begin{array}{c}198 \\
(188)\end{array}$ & $\begin{array}{c}220 \\
(157)\end{array}$ & $\begin{array}{c}22 \\
(46)\end{array}$ & $\begin{array}{c}46 \\
(130)\end{array}$ \\
\hline Effect of measure passage 2 years later & $\begin{array}{l}2586 \\
(563)\end{array}$ & $\begin{array}{c}853 \\
(235)\end{array}$ & $\begin{array}{c}792 \\
(228)\end{array}$ & $\begin{array}{l}-28 \\
(52)\end{array}$ & $\begin{array}{c}-6 \\
(185)\end{array}$ \\
\hline Effect of measure passage 3 years later & $\begin{array}{l}3408 \\
(563)\end{array}$ & $\begin{array}{l}1688 \\
(337)\end{array}$ & $\begin{array}{l}1549 \\
(299)\end{array}$ & $\begin{array}{l}-33 \\
(49)\end{array}$ & $\begin{array}{c}257 \\
(308)\end{array}$ \\
\hline Effect of measure passage 4 years later & $\begin{array}{l}3371 \\
(619)\end{array}$ & $\begin{array}{l}1841 \\
(417)\end{array}$ & $\begin{array}{l}1660 \\
(308)\end{array}$ & $\begin{array}{l}-64 \\
(64)\end{array}$ & $\begin{array}{c}169 \\
(211)\end{array}$ \\
\hline Effect of measure passage 5 years later & $\begin{array}{l}3425 \\
(691)\end{array}$ & $\begin{array}{l}1169 \\
(374)\end{array}$ & $\begin{array}{l}1091 \\
(268)\end{array}$ & $\begin{array}{l}-80 \\
(77)\end{array}$ & $\begin{array}{c}149 \\
(192)\end{array}$ \\
\hline Effect of measure passage 6 years later & $\begin{array}{l}3139 \\
(689)\end{array}$ & $\begin{array}{c}701 \\
(389)\end{array}$ & $\begin{array}{c}554 \\
(267)\end{array}$ & $\begin{array}{l}-82 \\
(80)\end{array}$ & $\begin{array}{c}87 \\
(215)\end{array}$ \\
\hline R2 & 0.72 & 0.61 & 0.32 & 0.83 & 0.59 \\
\hline
\end{tabular}

Notes: "Dynamic" specification is used following equation (8) in the text. The sample includes all available years of data and $\mathrm{N}=7,038$. All specifications include district fixed effects; a full set of absolute year indicators; indicators for the presence of a measure on the ballot in each relative year from 1 to +18 ; and interactions between the relative year indicators and an indicator for passage of the bond considered in that relative year, the required vote share, and a cubic polynomial in the actual vote share. Only the bond passage interactions for $[+1,+6]$ (i.e. for the six years prior to the year in which the outcome is measured) are shown. Standard errors are clustered on the school district. Dependent variables are measured in constant year-2000 dollars per pupil. 
Table 6. Dynamic RD alternative specifications for fiscal outcomes in 4th year after election

LT debt PP

Total expenditures PP

Capital outlays PP

Curr. instr. expend. PP

State aid PP

\begin{tabular}{|c|c|c|c|c|c|c|c|c|}
\hline \multirow[b]{2}{*}{$\begin{array}{l}\text { Base } \\
\text { (cubic) }\end{array}$} & \multirow[b]{2}{*}{ Linear } & \multirow[b]{2}{*}{$\begin{array}{l}\text { 3-part } \\
\text { linear }\end{array}$} & \multirow[b]{2}{*}{$\begin{array}{l}\text { 3-part } \\
\text { cubic }\end{array}$} & \multicolumn{3}{|c|}{ Placebo thresholds } & \multirow[b]{2}{*}{$\begin{array}{l}\text { High capital } \\
\text { spending } \\
\text { districts }\end{array}$} & \multirow[b]{2}{*}{$\begin{array}{l}\text { Low capital } \\
\text { spending } \\
\text { districts }\end{array}$} \\
\hline & & & & $\begin{array}{c}\text { Switch } \\
55 \% \text { \& } \\
67 \%\end{array}$ & $\begin{array}{c}\text { Actual } \\
\text { minus } 10\end{array}$ & $\begin{array}{l}\text { Actual } \\
\text { plus } 10\end{array}$ & & \\
\hline
\end{tabular}

\begin{tabular}{ccccccccc}
\hline$(1)$ & $(2)$ & $(3)$ & $(4)$ & $(5)$ & $(6)$ & $(7)$ & $(8)$ & $(9)$ \\
\hline $\mathbf{3 3 7 1}$ & $\mathbf{3 7 3 3}$ & $\mathbf{3 6 8 9}$ & $\mathbf{3 5 3 4}$ & -190 & -542 & 1777 & $\mathbf{1 7 1 1}$ & $\mathbf{2 8 2 6}$ \\
$(619)$ & $(596)$ & $(583)$ & $(873)$ & $(382)$ & $(816)$ & $(984)$ & $(813)$ & $(621)$ \\
$\mathbf{1 8 4 1}$ & $\mathbf{1 8 4 8}$ & $\mathbf{1 7 9 6}$ & $\mathbf{1 8 0 8}$ & -100 & 167 & 891 & $\mathbf{1 4 3 6}$ & $\mathbf{1 2 7 3}$ \\
$(417)$ & $(361)$ & $(385)$ & $(452)$ & $(219)$ & $(386)$ & $(488)$ & $(502)$ & $(404)$ \\
$\mathbf{1 6 6 0}$ & $\mathbf{1 6 6 4}$ & $\mathbf{1 5 8 6}$ & $\mathbf{1 5 2 7}$ & -234 & 82 & 544 & $\mathbf{1 3 0 0}$ & $\mathbf{1 2 3 3}$ \\
$(308)$ & $(268)$ & $(270)$ & $(421)$ & $(170)$ & $(307)$ & $(387)$ & $(471)$ & $(336)$ \\
-64 & -80 & -65 & 21 & 75 & 110 & 55 & 34 & -67 \\
$(64)$ & $(58)$ & $(58)$ & $(86)$ & $(55)$ & $(93)$ & $(76)$ & $(73)$ & $(63)$ \\
169 & 277 & 190 & 393 & -121 & 0 & $\mathbf{6 1 5}$ & -91 & -120 \\
$(211)$ & $(192)$ & $(199)$ & $(230)$ & $(136)$ & $(249)$ & $(211)$ & $(309)$ & $(259)$
\end{tabular}

Notes: Each cell represents a separate regression. Specification in column 1 is that used in Table 5; only the coefficient for measure passage four years prior is shown. Column 2 replaces the cubic vote share control (interacted with relative year indicators) with a linear vote share control; column 3 uses separate linear segments in the $[0,55]$, [55, 66.7], and [66.7, 100] ranges; and column 4 uses separate cubic segments in each range. Columns 5-7 include the actual measure passage indicator as well as counterfactual indicators that reflect vote shares in excess of alternative thresholds. Columns 8 and 9 use the "static" specification from Table 4, restricting the sample to measures where capital spending in the year before the election was above (col. 8) or below (col. 9) \$562 per pupil, the median across all measures. Standard errors are clustered on the school district.

Table 7. Static and Dynamic RD estimates of effect of bond passage on housing prices

\begin{tabular}{|c|c|c|c|c|}
\hline & \multicolumn{2}{|c|}{ Static } & \multicolumn{2}{|c|}{ Dynamic } \\
\hline & Prices & Log prices & Prices & Log prices \\
\hline & (1) & (2) & (3) & (4) \\
\hline \multirow[t]{2}{*}{ Effect of measure passage in year of election } & 12232 & 0.021 & 10907 & 0.030 \\
\hline & (5107) & $(0.015)$ & $(6922)$ & $(0.017)$ \\
\hline \multirow[t]{2}{*}{ Effect of measure passage 1 year later } & 13691 & 0.027 & 13891 & 0.036 \\
\hline & (6247) & $(0.017)$ & (8046) & $(0.018)$ \\
\hline \multirow[t]{2}{*}{ Effect of measure passage 2 years later } & 13900 & 0.036 & 11758 & 0.042 \\
\hline & $(7872)$ & $(0.020)$ & $(9354)$ & $(0.020)$ \\
\hline \multirow[t]{2}{*}{ Effect of measure passage 3 years later } & 19251 & 0.058 & 14898 & 0.062 \\
\hline & $(9371)$ & $(0.022)$ & $(11290)$ & $(0.021)$ \\
\hline \multirow[t]{2}{*}{ Effect of measure passage 4 years later } & 18466 & 0.038 & 21667 & 0.052 \\
\hline & $(10473)$ & $(0.024)$ & $(11540)$ & $(0.022)$ \\
\hline \multirow[t]{2}{*}{ Effect of measure passage 5 years later } & 23188 & 0.038 & 28167 & 0.054 \\
\hline & $(11621)$ & $(0.027)$ & $(11829)$ & $(0.026)$ \\
\hline \multirow[t]{2}{*}{ Effect of measure passage 6 years later } & 13945 & 0.047 & 21139 & 0.067 \\
\hline & $(14485)$ & $(0.035)$ & $(14286)$ & $(0.034)$ \\
\hline R2 & 0.958 & 0.977 & 0.916 & 0.962 \\
\hline
\end{tabular}

Notes: Static and dynamic specifications are similar to those in Tables 4 and 5, respectively - see notes to those tables for details. Dynamic specifications include indicators for the presence of a measure on the ballot in each relative year from 0 to +19 . All housing price estimates also include controls for square footage, lot size and sales volume. Number of observations is 8,016 (cols. 1-2) and 10,313 (cols. 3-4). 
Table 8. Dynamic RD alternative specifications for housing prices in 5th year after election

\begin{tabular}{|c|c|c|c|c|c|c|c|c|c|}
\hline & \multirow[b]{2}{*}{$\begin{array}{l}\text { Base } \\
\text { (cubic) }\end{array}$} & \multirow[b]{2}{*}{ Linear } & \multirow[b]{2}{*}{$\begin{array}{l}\text { 3-part } \\
\text { linear }\end{array}$} & \multirow[b]{2}{*}{$\begin{array}{l}\text { 3-part } \\
\text { cubic }\end{array}$} & \multicolumn{3}{|c|}{ Placebo thresholds } & \multicolumn{2}{|c|}{ Other elections } \\
\hline & & & & & $\begin{array}{c}\text { Switch } \\
55 \% \& \\
67 \%\end{array}$ & $\begin{array}{c}\text { Actual } \\
\text { minus } 10\end{array}$ & $\begin{array}{l}\text { Actual } \\
\text { plus } 10\end{array}$ & $\begin{array}{l}\text { Bond } \\
\text { effect }\end{array}$ & $\begin{array}{c}\text { Parcel tax } \\
\text { effect }\end{array}$ \\
\hline & $(1)$ & $(2)$ & (3) & $(4)$ & (5) & $(6)$ & $(7)$ & $(8)$ & $(9)$ \\
\hline Prices & $\begin{array}{c}28167 \\
(11829)\end{array}$ & $\begin{array}{c}\mathbf{3 4 4 3 4} \\
(11130)\end{array}$ & $\begin{array}{c}27258 \\
(13027)\end{array}$ & $\begin{array}{c}36455 \\
(20306)\end{array}$ & $\begin{array}{c}-51409 \\
(20917)\end{array}$ & $\begin{array}{c}-2974 \\
(17543)\end{array}$ & $\begin{array}{c}34787 \\
(24784)\end{array}$ & $\begin{array}{c}\mathbf{3 3 8 0 7} \\
(10504)\end{array}$ & $\begin{array}{c}-3862 \\
(27035)\end{array}$ \\
\hline Log prices & $\begin{array}{c}\mathbf{0 . 0 5 4} \\
(0.026)\end{array}$ & $\begin{array}{c}\mathbf{0 . 0 6 4} \\
(0.024)\end{array}$ & $\begin{array}{c}0.042 \\
(0.030)\end{array}$ & $\begin{array}{c}\mathbf{0 . 1 3 0} \\
(0.056)\end{array}$ & $\begin{array}{c}-0.048 \\
(0.036)\end{array}$ & $\begin{array}{c}0.054 \\
(0.035)\end{array}$ & $\begin{array}{l}-0.032 \\
(0.034)\end{array}$ & $\begin{array}{c}\mathbf{0 . 0 6 8} \\
(0.023)\end{array}$ & $\begin{array}{c}0.023 \\
(0.038)\end{array}$ \\
\hline
\end{tabular}

Notes: Each cell represents a separate regression. Specification in column 1 is that used in Table 7, Columns 3-4; only the coefficients for measure passage five years prior are shown. Column 2 replaces the cubic vote share control (interacted with relative year indicators) with a linear vote share control; column 3 uses separate linear segments in the $[0,55],[55,66.7]$, and $[66.7,100]$ ranges; and column 4 uses separate cubic segments in each range. Columns 5-7 include the actual measure passage indicator as well as counterfactual indicators that reflect vote shares in excess of alternative thresholds. Columns 8 and 9 come from the same specifications, with all of the controls from column 1 plus controls and all interactions for parcel tax measures. The "win" coefficients for bond measures are in column 8 , and those for parcel tax measures are in column 9. Standard errors are clustered on the school district.

Table 9. Static and Dynamic RD estimates of effect of bond passage on third grade test scores

\begin{tabular}{|c|c|c|c|c|}
\hline & \multicolumn{2}{|c|}{ Static } & \multicolumn{2}{|c|}{ Dynamic } \\
\hline & $\begin{array}{l}\text { Reading } \\
\text { (1) }\end{array}$ & $\begin{array}{l}\text { Math } \\
(2)\end{array}$ & $\begin{array}{l}\text { Reading } \\
\text { (3) }\end{array}$ & $\begin{array}{l}\text { Math } \\
(4)\end{array}$ \\
\hline \multirow[t]{2}{*}{ Effect of measure passage 1 year later } & 0.027 & 0.038 & -0.010 & -0.012 \\
\hline & (0.045) & $(0.056)$ & $(0.054)$ & (0.057) \\
\hline \multirow[t]{2}{*}{ Effect of measure passage 2 years later } & 0.008 & -0.006 & -0.023 & -0.034 \\
\hline & $(0.048)$ & $(0.058)$ & $(0.051)$ & $(0.054)$ \\
\hline \multirow[t]{2}{*}{ Effect of measure passage 3 years later } & 0.061 & 0.043 & 0.058 & 0.030 \\
\hline & $(0.053)$ & $(0.069)$ & $(0.053)$ & $(0.062)$ \\
\hline \multirow[t]{2}{*}{ Effect of measure passage 4 years later } & 0.013 & 0.039 & -0.026 & 0.026 \\
\hline & $(0.061)$ & $(0.072)$ & $(0.058)$ & $(0.062)$ \\
\hline \multirow[t]{2}{*}{ Effect of measure passage 5 years later } & 0.076 & 0.086 & 0.039 & 0.058 \\
\hline & (0.061) & $(0.077)$ & (0.061) & (0.069) \\
\hline \multirow[t]{2}{*}{ Effect of measure passage 6 years later } & 0.151 & 0.185 & 0.103 & 0.160 \\
\hline & $(0.065)$ & $(0.080)$ & $(0.064)$ & $(0.075)$ \\
\hline $\mathrm{R} 2$ & 0.933 & 0.902 & 0.880 & 0.842 \\
\hline
\end{tabular}

Notes: Static and dynamic specifications are similar to those in Tables 4 and 5, respectively - see the notes to those tables for details. Dynamic specifications include indicators for the presence of a measure on the ballot in each relative year from -14 to +19 . Number of observations is 6,084 (cols 1-2) and 6,660 (cols. 3-4). 
Table 10. Dynamic RD estimates of effect of bond passage on house sales and homebuyer and student characteristics

\begin{tabular}{|c|c|c|c|c|c|c|c|}
\hline & $\begin{array}{c}1 \text { yr later } \\
\text { (1) }\end{array}$ & $\begin{array}{c}2 \text { yrs later } \\
\text { (2) }\end{array}$ & $\begin{array}{c}3 \text { yrs later } \\
\text { (3) }\end{array}$ & $\begin{array}{c}4 \text { yrs later } \\
\text { (4) }\end{array}$ & $\begin{array}{c}5 \text { yrs later } \\
\text { (5) }\end{array}$ & $\begin{array}{c}6 \text { yrs later } \\
(6)\end{array}$ & $\begin{array}{l}\mathrm{N} \\
(7)\end{array}$ \\
\hline A. Housing market transactions & & & & & & & \\
\hline Sales volume & $\begin{array}{c}93 \\
(78)\end{array}$ & $\begin{array}{l}207 \\
(89)\end{array}$ & $\begin{array}{l}282 \\
(93)\end{array}$ & $\begin{array}{l}213 \\
(98)\end{array}$ & $\begin{array}{c}241 \\
(116)\end{array}$ & $\begin{array}{c}325 \\
(115)\end{array}$ & 10857 \\
\hline Log sales volume & $\begin{array}{l}-0.001 \\
(0.056)\end{array}$ & $\begin{array}{c}0.041 \\
(0.062)\end{array}$ & $\begin{array}{c}0.031 \\
(0.066)\end{array}$ & $\begin{array}{l}-0.005 \\
(0.068)\end{array}$ & $\begin{array}{c}0.032 \\
(0.070)\end{array}$ & $\begin{array}{c}0.039 \\
(0.073)\end{array}$ & 10857 \\
\hline $\begin{array}{l}\text { B. Homebuyer characteristics } \\
\text { Income }\end{array}$ & $\begin{array}{c}3245 \\
(2624)\end{array}$ & $\begin{array}{c}1042 \\
(2645)\end{array}$ & $\begin{array}{l}-2384 \\
(3113)\end{array}$ & $\begin{array}{c}4212 \\
(3435)\end{array}$ & $\begin{array}{c}1486 \\
(3218)\end{array}$ & $\begin{array}{c}450 \\
(3391)\end{array}$ & 9921 \\
\hline Log income & $\begin{array}{c}0.027 \\
(0.019)\end{array}$ & $\begin{array}{c}0.017 \\
(0.021)\end{array}$ & $\begin{array}{l}-0.005 \\
(0.023)\end{array}$ & $\begin{array}{c}0.035 \\
(0.025)\end{array}$ & $\begin{array}{l}-0.008 \\
(0.025)\end{array}$ & $\begin{array}{c}0.004 \\
(0.024)\end{array}$ & 9921 \\
\hline Fr. white \& Asian & $\begin{array}{c}0.017 \\
(0.009)\end{array}$ & $\begin{array}{c}0.000 \\
(0.009)\end{array}$ & $\begin{array}{c}0.001 \\
(0.010)\end{array}$ & $\begin{array}{c}0.004 \\
(0.010)\end{array}$ & $\begin{array}{c}0.001 \\
(0.011)\end{array}$ & $\begin{array}{c}-0.008 \\
(0.011)\end{array}$ & 9921 \\
\hline C. School district characteristics & & & & & & & \\
\hline Log enrollment, all grades & $\begin{array}{r}-0.012 \\
(0.017)\end{array}$ & $\begin{array}{c}-0.011 \\
(0.020)\end{array}$ & $\begin{array}{c}0.010 \\
(0.025)\end{array}$ & $\begin{array}{c}0.001 \\
(0.039)\end{array}$ & $\begin{array}{c}0.001 \\
(0.035)\end{array}$ & $\begin{array}{c}-0.007 \\
(0.042)\end{array}$ & 7,038 \\
\hline Log enrollment, Kindergarten & $\begin{array}{c}0.018 \\
(0.022)\end{array}$ & $\begin{array}{l}-0.001 \\
(0.023)\end{array}$ & $\begin{array}{c}0.009 \\
(0.028)\end{array}$ & $\begin{array}{c}0.000 \\
(0.028)\end{array}$ & $\begin{array}{l}-0.030 \\
(0.032)\end{array}$ & $\begin{array}{l}-0.004 \\
(0.034)\end{array}$ & 5,899 \\
\hline Log enrollment, 1st grade & $\begin{array}{l}-0.006 \\
(0.021)\end{array}$ & $\begin{array}{c}0.003 \\
(0.022)\end{array}$ & $\begin{array}{c}0.005 \\
(0.028)\end{array}$ & $\begin{array}{c}0.017 \\
(0.029)\end{array}$ & $\begin{array}{c}-0.018 \\
(0.031)\end{array}$ & $\begin{array}{l}-0.017 \\
(0.034)\end{array}$ & 5,877 \\
\hline Fr. white \& Asian, all grades & $\begin{array}{l}-0.002 \\
(0.005)\end{array}$ & $\begin{array}{c}0.004 \\
(0.006)\end{array}$ & $\begin{array}{c}0.002 \\
(0.008)\end{array}$ & $\begin{array}{c}0.005 \\
(0.008)\end{array}$ & $\begin{array}{c}0.008 \\
(0.009)\end{array}$ & $\begin{array}{c}0.004 \\
(0.010)\end{array}$ & 7,035 \\
\hline Fr. white \& Asian, Kindergarten & $\begin{array}{c}0.016 \\
(0.011)\end{array}$ & $\begin{array}{c}\mathbf{0 . 0 2 6} \\
(0.013)\end{array}$ & $\begin{array}{c}\mathbf{0 . 0 3 8} \\
(0.014)\end{array}$ & $\begin{array}{c}\mathbf{0 . 0 4 2} \\
(0.017)\end{array}$ & $\begin{array}{c}\mathbf{0 . 0 5 6} \\
(0.021)\end{array}$ & $\begin{array}{c}\mathbf{0 . 0 5 0} \\
(0.018)\end{array}$ & 4,279 \\
\hline Fr. white \& Asian, 1st grade & $\begin{array}{l}-0.004 \\
(0.010)\end{array}$ & $\begin{array}{c}0.008 \\
(0.011)\end{array}$ & $\begin{array}{c}0.011 \\
(0.012)\end{array}$ & $\begin{array}{c}0.025 \\
(0.014)\end{array}$ & $\begin{array}{c}0.027 \\
(0.016)\end{array}$ & $\begin{array}{c}0.006 \\
(0.016)\end{array}$ & 4,263 \\
\hline Avg. parental education, all grades & $\begin{array}{l}-0.060 \\
(0.096)\end{array}$ & $\begin{array}{l}-0.218 \\
(0.170)\end{array}$ & $\begin{array}{l}-0.018 \\
(0.156)\end{array}$ & $\begin{array}{c}-0.169 \\
(0.218)\end{array}$ & $\begin{array}{c}-0.163 \\
(0.161)\end{array}$ & $\begin{array}{c}0.005 \\
(0.149)\end{array}$ & 6978 \\
\hline
\end{tabular}

Notes: All regressions use the dynamic specification - see notes to Table 5 for details. Kindergarten and 1st grade enrollments and racial shares exclude districts with grade-level enrollment below 50 . 
Figure 1. Density of bond measures by vote share
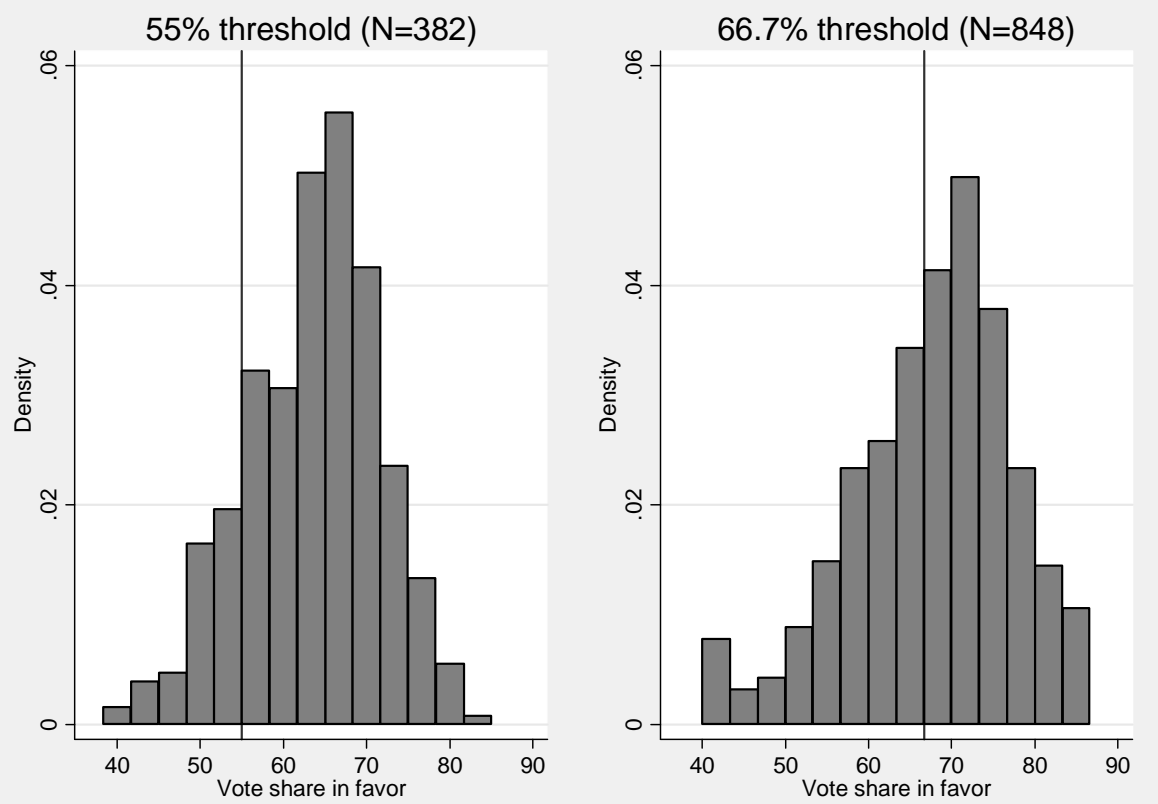

Notes: Vote shares are censored at 40 and 85.

Figure 2. Number of additional measures considered and passed within four years following bond measure election, by margin of victory/defeat
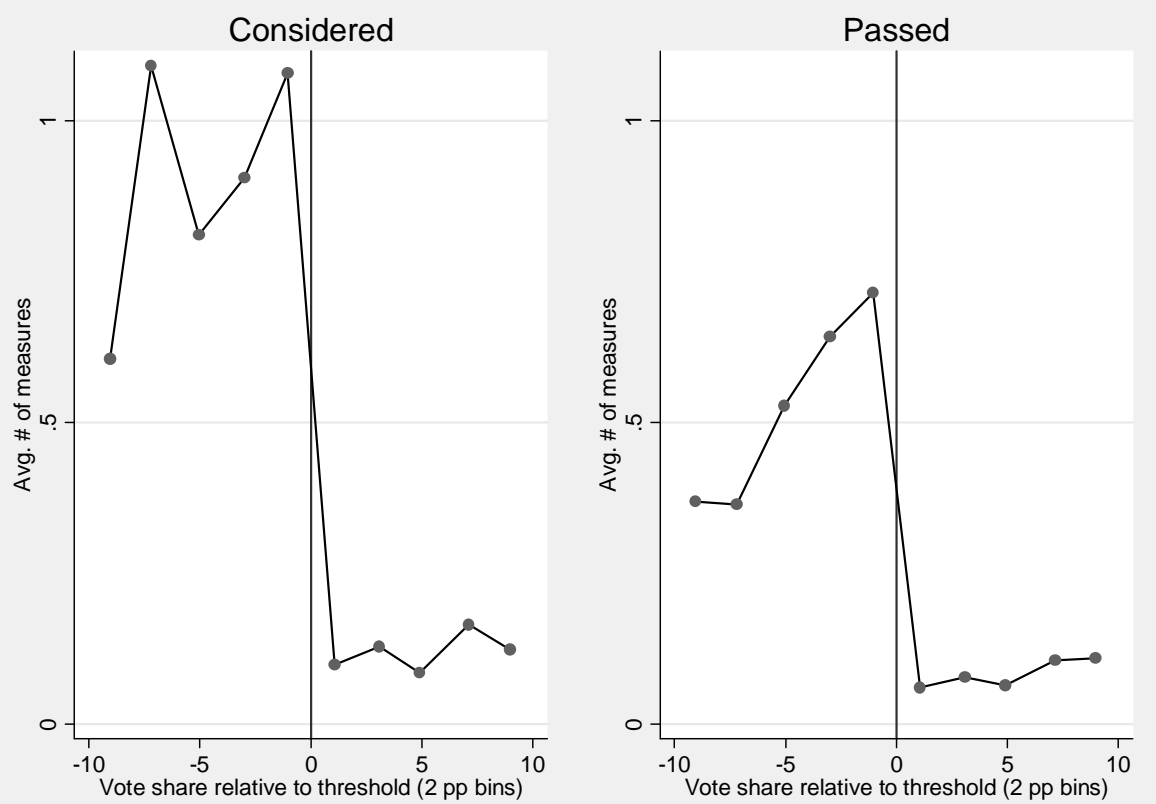

Notes: Graphs show average number of measures considered or passed in years 1,2,3, and 4 after the focal election, by the vote share in that focal election. Bins are two percentage points wide: Measures that passed by between $0.001 \%$ and $2 \%$ are assigned to the 1 bin; those that failed by similar margins are assigned to the -1 bin. 
Figure 3. Static RD estimates of the effect of bond passage on the number of measures passed since the year of the focal election

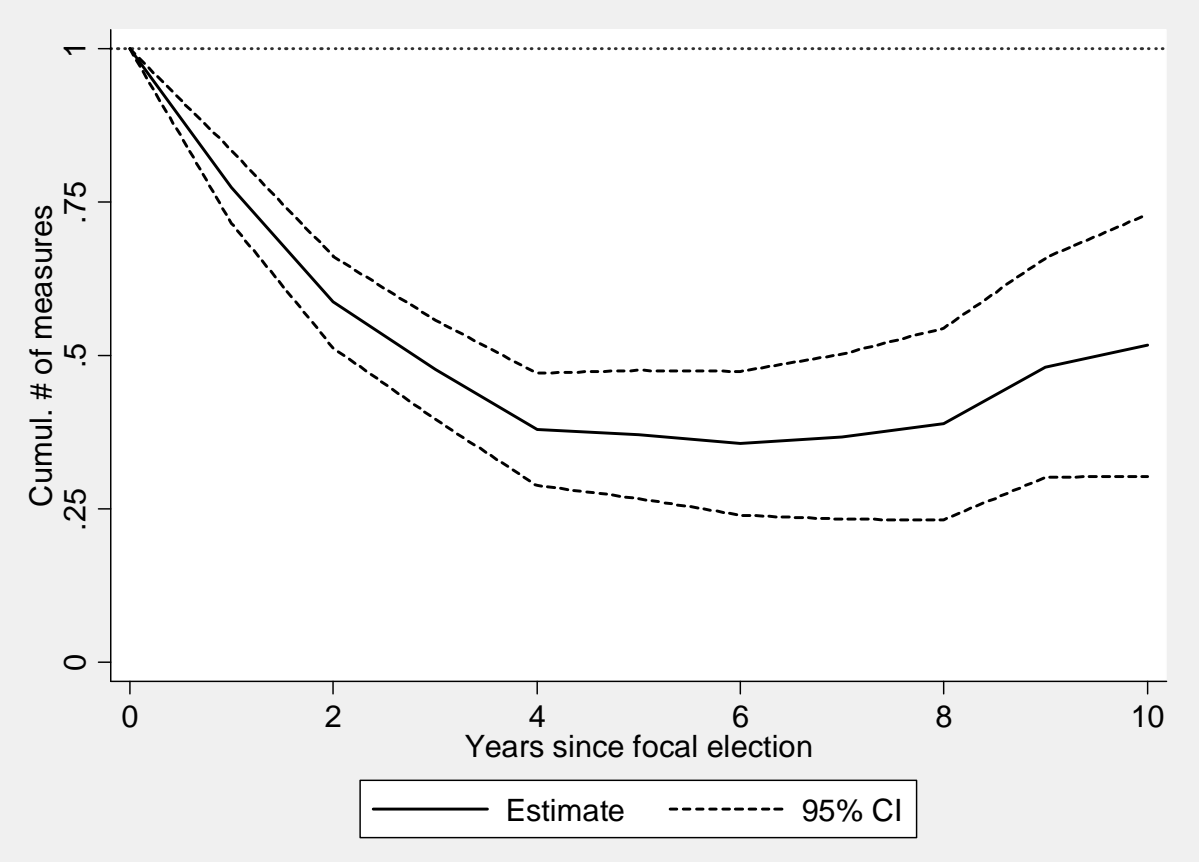

Notes: Graph shows coefficients and 95\% confidence intervals from RD regressions of the cumulative number of measures approved since the year before the election on an indicator for measure passage, controlling for a cubic in the vote share and an indicator for a 55\% requirement. Regressions are estimated separately for each relative year.

Figure 4. Long term debt per pupil, by vote share, one year before and three years after election

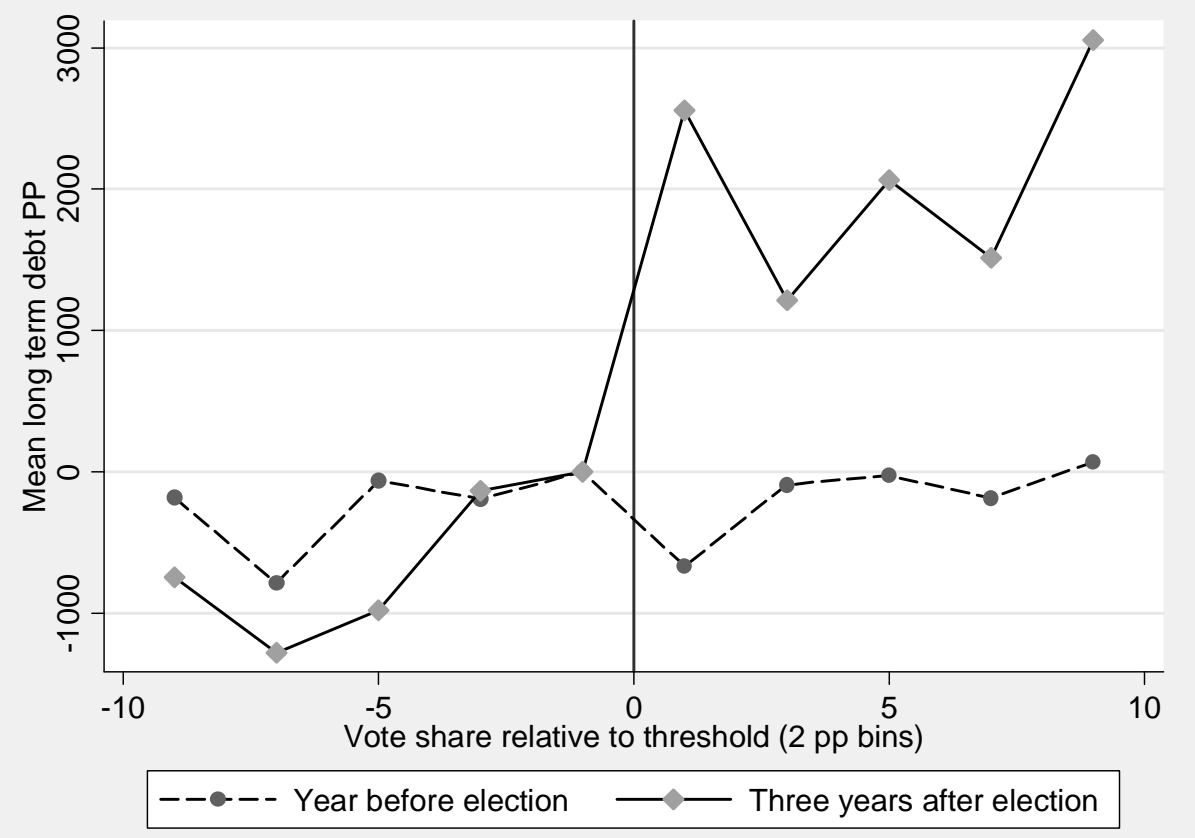

Notes: Graph shows average long term debt per pupil in each bin in the listed year relative to the election. Averages are conditional on year fixed effects, and the -1 bin is normalized to zero. Measures that passed by between $0.001 \%$ and $2 \%$ are assigned to the 1 bin; those that failed by similar margins are assigned to the -1 bin. 
Figure 5. Capital outlays per pupil, by vote share, one year before and three years after election

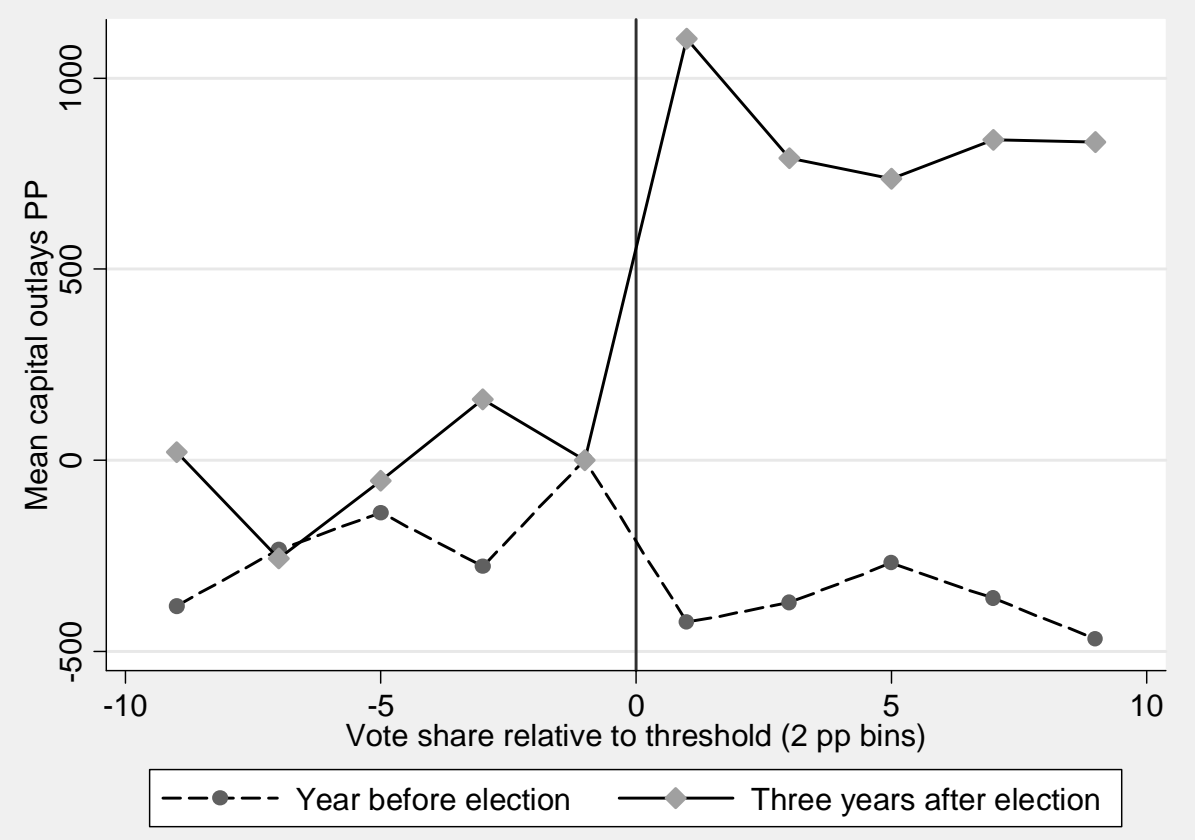

Notes: Graph shows average capital outlays per pupil in each bin in the listed year relative to the election. Averages are conditional on year fixed effects, and the -1 bin is normalized to zero. Measures that passed by between $0.001 \%$ and $2 \%$ are assigned to the $1 \mathrm{bin}$; those that failed by similar margins are assigned to the -1 bin.

Figure 6. Current instructional expenditures per pupil, by vote share, one year before and three years after election

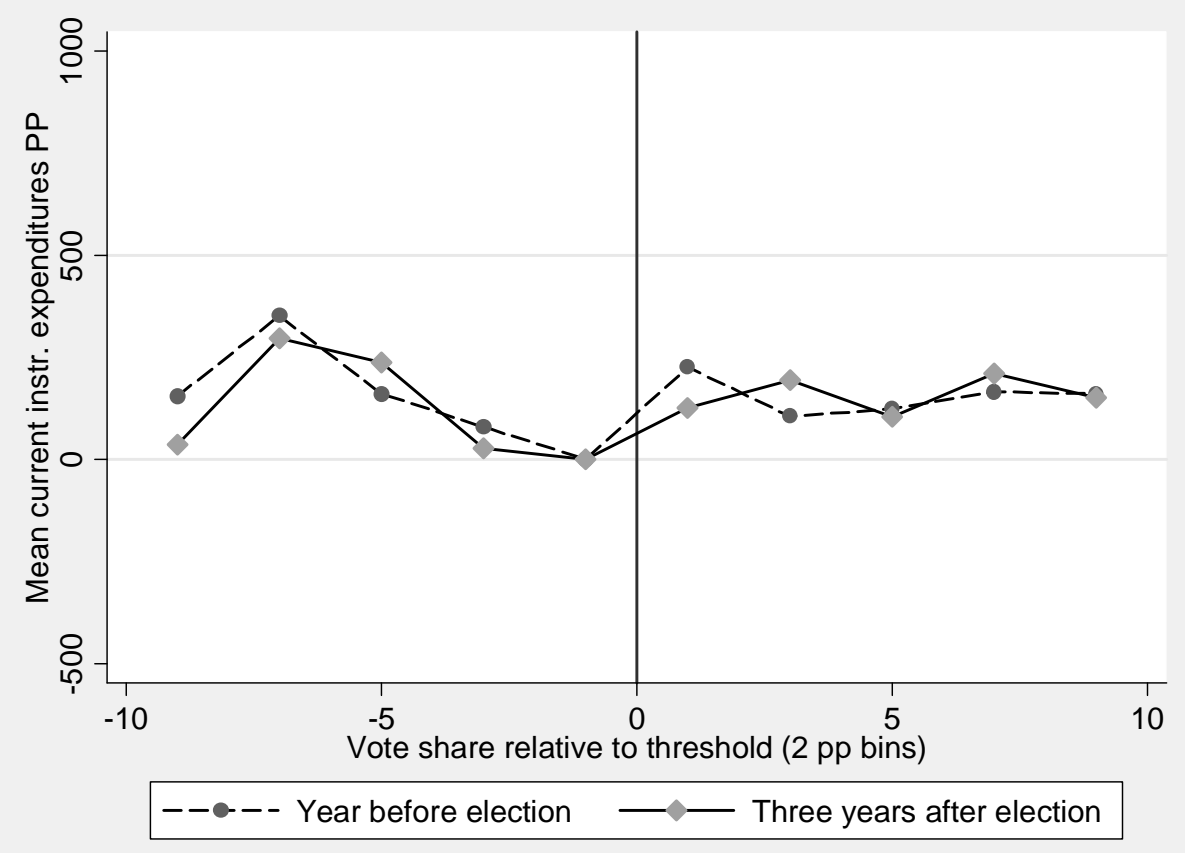

Notes: Graph shows average current instructional expenditures per pupil in each bin in the listed year relative to the election. Averages are conditional on year fixed effects, and the -1 bin is normalized to zero. Measures that passed by between $0.001 \%$ and $2 \%$ are assigned to the $1 \mathrm{bin}$; those that failed by similar margins are assigned to the -1 bin. 
Figure 7. Static and dynamic RD estimates of effect of bond passage on capital outlays per pupil

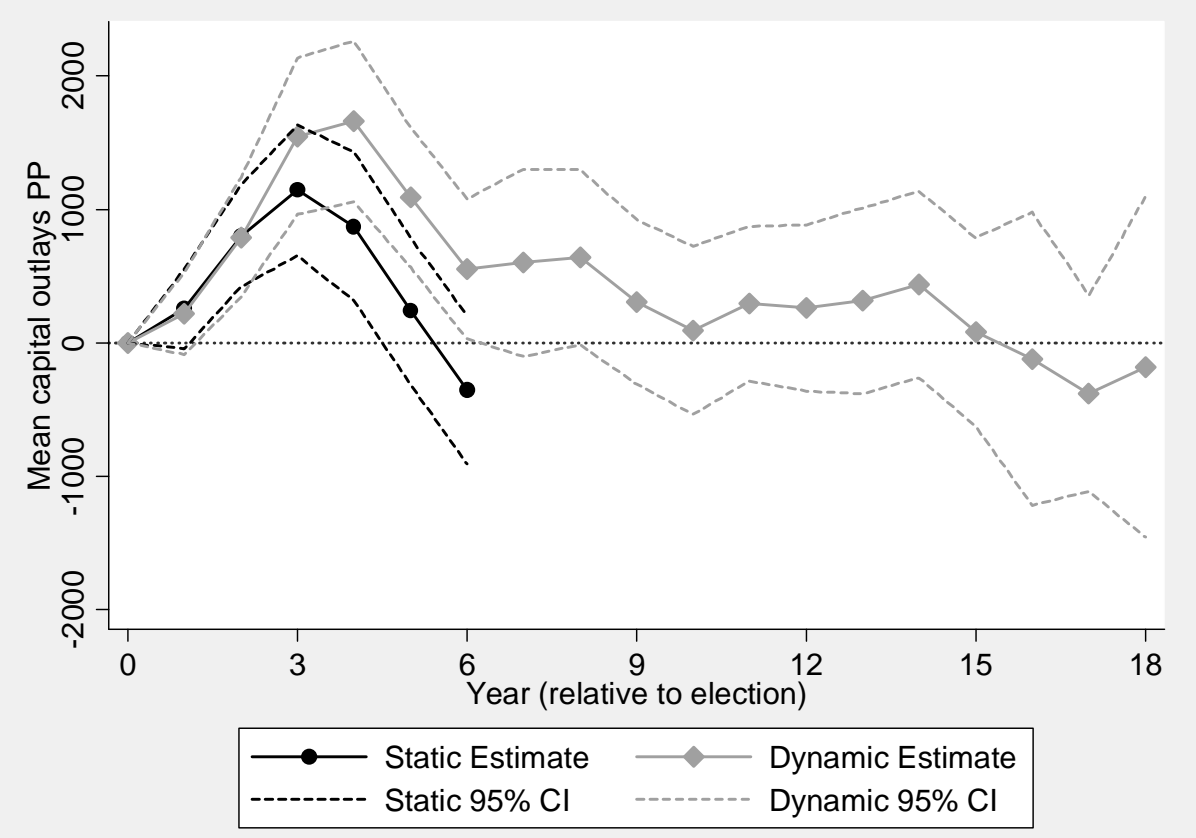

Notes: Graph shows coefficients and 95\% confidence intervals from estimates of the "static" and "dynamic" RD specifications reported in Column 3 of Tables 4 and 5, respectively.

Figure 8 . Log housing prices by vote share, one year before and three years after election

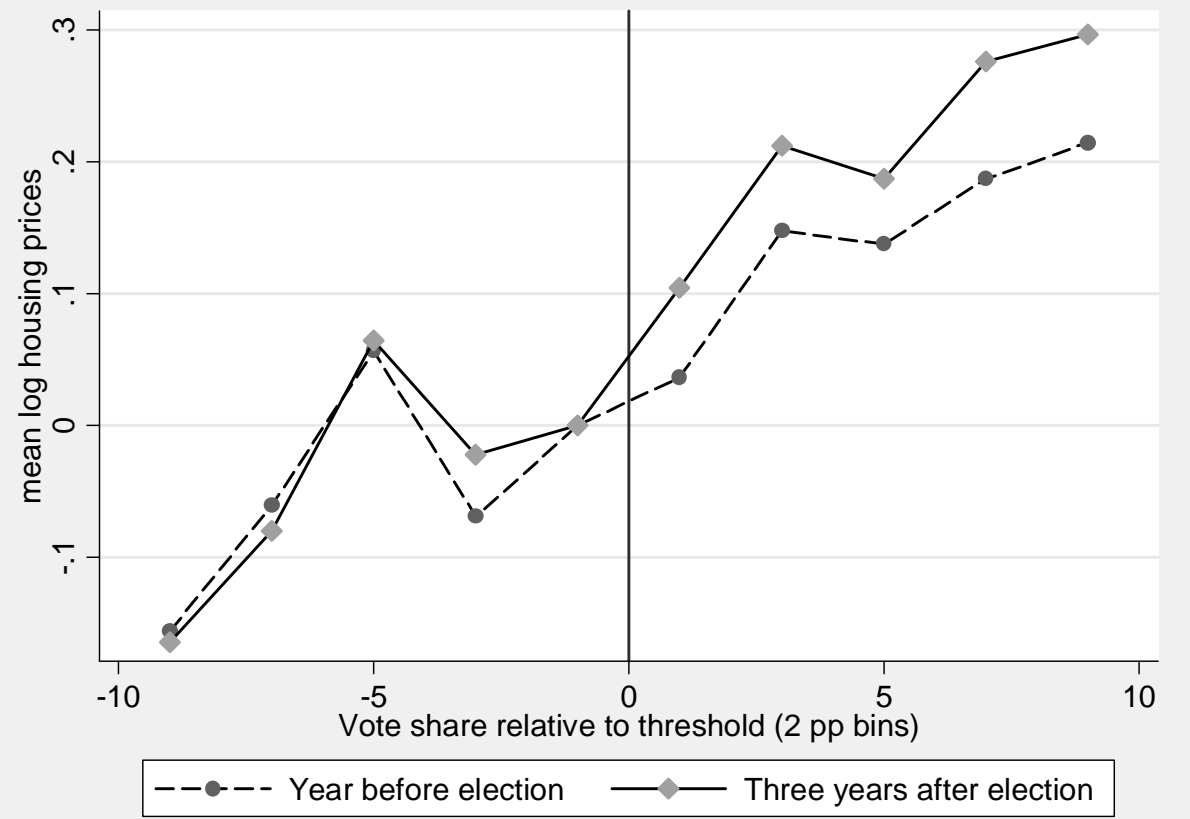

Notes: Graph shows average log housing prices in each bin in the listed year relative to the election. Averages are conditional on year fixed effects and the -1 bin was normalized to zero. Measures that passed by between $0.001 \%$ and $2 \%$ are assigned to the $1 \mathrm{bin}$; those that failed by similar margins are assigned to the -1 bin. 
Figure 9. Static and dynamic RD estimates of effect of bond passage on log housing prices

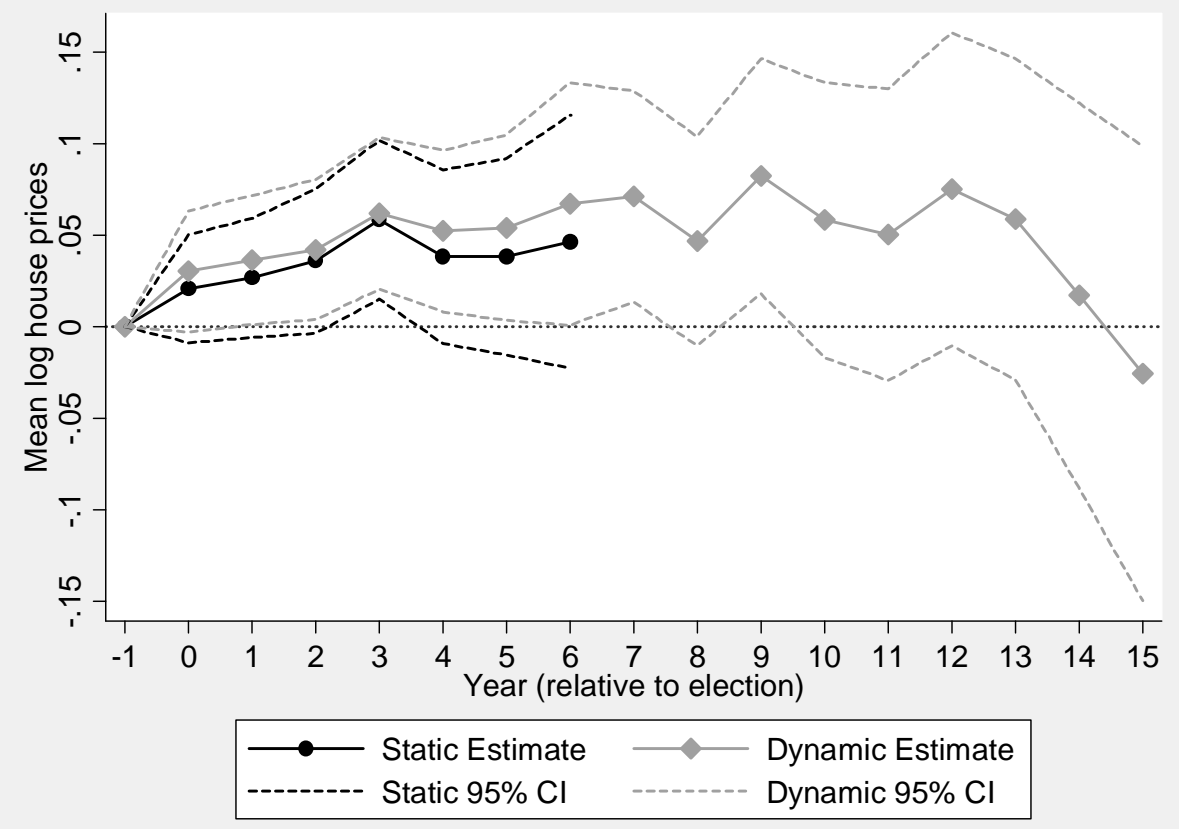

Notes: Graph shows coefficients and 95\% confidence intervals from estimates of the "static" and "dynamic" RD specifications reported in Columns 2 and 4, respectively, of Table 7. To preserve a readable scale, tears 16-18 are not shown.

Figure 10. Static and dynamic RD estimates of effect of bond passage on test scores

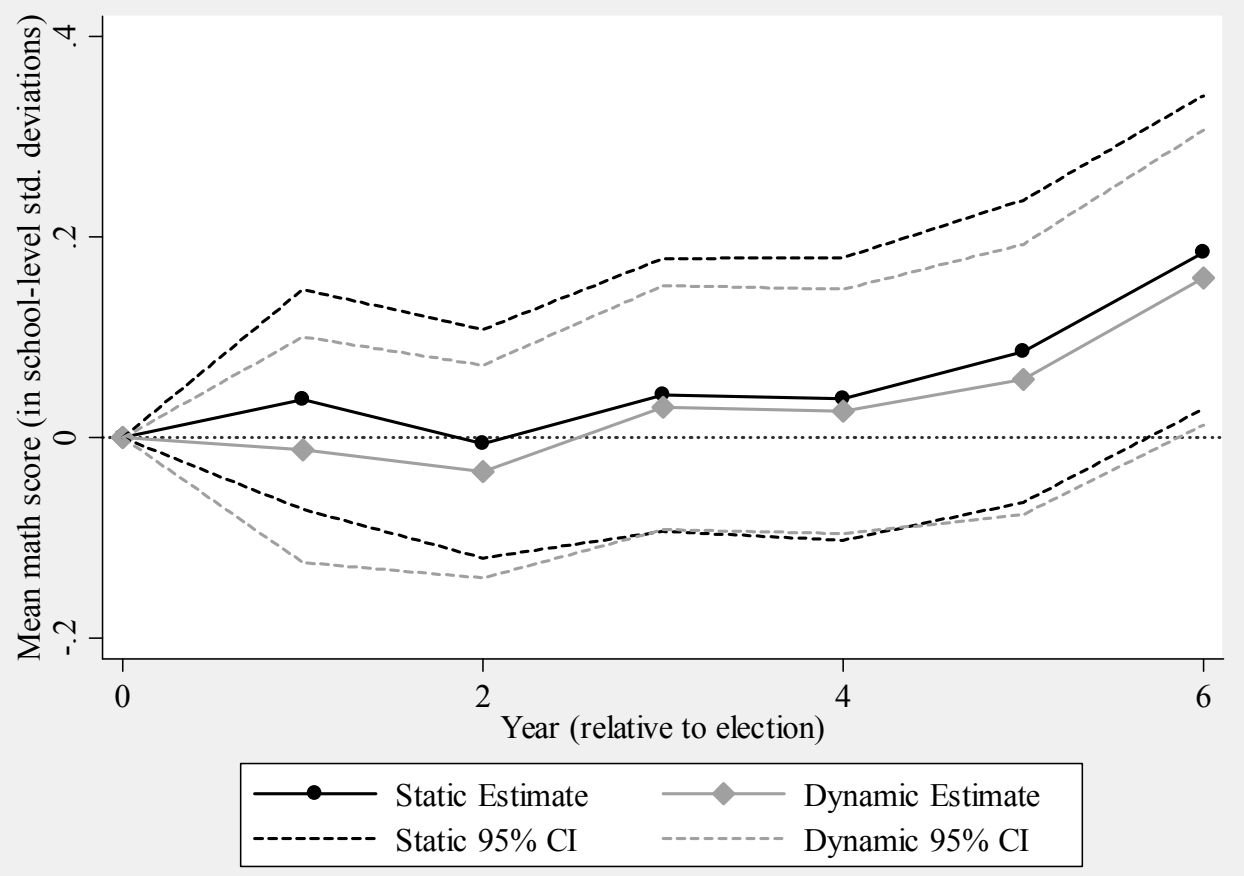

Notes: Graph shows coefficients and 95\% confidence intervals from estimates of the "static" and "dynamic" RD specifications, reported in Columns 2 and 4, respectively, of Table 9. Only years 1-6 are shown. 
Appendix Table 1. Dynamic RD estimates of effect of bond passage on district balance sheet

\begin{tabular}{|c|c|c|c|c|c|c|}
\hline & $\begin{array}{c}1 \text { yr later } \\
(1)\end{array}$ & $\begin{array}{c}2 \text { yrs later } \\
\text { (2) }\end{array}$ & $\begin{array}{c}3 \text { yrs later } \\
\text { (3) }\end{array}$ & $\begin{array}{c}4 \text { yrs later } \\
(4)\end{array}$ & $\begin{array}{c}5 \text { yrs later } \\
\text { (5) }\end{array}$ & $\begin{array}{c}6 \text { yrs later } \\
(6)\end{array}$ \\
\hline \multirow[t]{2}{*}{$\underline{\text { Total revenues }}$} & 288 & 458 & 899 & 741 & 657 & 667 \\
\hline & (201) & $(271)$ & $(479)$ & $(436)$ & $(450)$ & $(497)$ \\
\hline \multirow[t]{2}{*}{ Federal revenuse } & -5 & -44 & -73 & -65 & -58 & -93 \\
\hline & (21) & (26) & (34) & (32) & (41) & $(46)$ \\
\hline \multirow[t]{2}{*}{ State revenues } & 46 & -6 & 257 & 169 & 149 & 87 \\
\hline & $(130)$ & $(185)$ & $(308)$ & $(211)$ & $(192)$ & $(215)$ \\
\hline \multirow[t]{2}{*}{ Local revenues } & 248 & 508 & 715 & 637 & 566 & 673 \\
\hline & (156) & $(220)$ & $(265)$ & (356) & $(400)$ & $(427)$ \\
\hline \multirow[t]{2}{*}{ Loc. rev. - property tax collections } & 112 & 253 & 372 & 387 & 422 & 410 \\
\hline & (78) & $(159)$ & $(162)$ & (313) & $(300)$ & $(321)$ \\
\hline \multirow[t]{2}{*}{ Loc. rev. - interest earned } & 44 & 127 & 123 & 110 & 74 & 84 \\
\hline & (23) & $(21)$ & (35) & (61) & $(61)$ & (63) \\
\hline \multirow[t]{2}{*}{ Loc. rev. - all other } & 91 & 129 & 221 & 140 & 70 & 178 \\
\hline & $(140)$ & $(129)$ & $(165)$ & $(108)$ & $(108)$ & $(139)$ \\
\hline \multirow[t]{2}{*}{ Total expenditures } & 198 & 853 & 1,688 & 1,841 & 1,169 & 701 \\
\hline & (188) & $(235)$ & (337) & $(417)$ & (374) & (389) \\
\hline Current elementary/secondary & $\begin{array}{c}3 \\
(68)\end{array}$ & $\begin{array}{l}-13 \\
(96)\end{array}$ & $\begin{array}{c}-6 \\
(105)\end{array}$ & $\begin{array}{c}12 \\
(170)\end{array}$ & $\begin{array}{c}-61 \\
(168)\end{array}$ & $\begin{array}{c}-49 \\
(184)\end{array}$ \\
\hline Instructional & $\begin{array}{c}22 \\
(46)\end{array}$ & $\begin{array}{l}-28 \\
(52)\end{array}$ & $\begin{array}{l}-33 \\
(49)\end{array}$ & $\begin{array}{l}-64 \\
(64)\end{array}$ & $\begin{array}{l}-80 \\
(77)\end{array}$ & $\begin{array}{l}-82 \\
(80)\end{array}$ \\
\hline Operation and maintenance of plant & $\begin{array}{l}-25 \\
(35)\end{array}$ & $\begin{array}{l}-81 \\
(48)\end{array}$ & $\begin{array}{l}-84 \\
(54)\end{array}$ & $\begin{array}{l}-83 \\
(57)\end{array}$ & $\begin{array}{c}4 \\
(53)\end{array}$ & $\begin{array}{l}-13 \\
(67)\end{array}$ \\
\hline Other & $\begin{array}{c}6 \\
(44)\end{array}$ & $\begin{array}{c}96 \\
(59)\end{array}$ & $\begin{array}{l}111 \\
(74)\end{array}$ & $\begin{array}{c}160 \\
(130)\end{array}$ & $\begin{array}{c}16 \\
(128)\end{array}$ & $\begin{array}{c}47 \\
(137)\end{array}$ \\
\hline \multirow[t]{2}{*}{ Non-elementary/secondary } & -42 & -9 & -22 & 0 & 16 & 17 \\
\hline & (24) & (16) & $(18)$ & $(22)$ & $(26)$ & (28) \\
\hline \multirow[t]{2}{*}{ Capital outlays } & 220 & 792 & 1,549 & 1,660 & 1,091 & 554 \\
\hline & $(157)$ & $(228)$ & (299) & $(308)$ & (268) & $(267)$ \\
\hline \multirow[t]{2}{*}{ Intergovernmental payments } & 8 & 19 & 34 & 44 & 14 & 67 \\
\hline & (15) & (35) & (37) & $(58)$ & (77) & (83) \\
\hline \multirow[t]{2}{*}{ Interest on debt } & 9 & 65 & 132 & 125 & 108 & 112 \\
\hline & (13) & $(23)$ & $(27)$ & (30) & (33) & (31) \\
\hline \multirow[t]{2}{*}{$\underline{\text { Revenues minus expenditures }}$} & 90 & -395 & -789 & $-1,100$ & -512 & -35 \\
\hline & $(185)$ & (286) & (324) & $(257)$ & $(282)$ & $(290)$ \\
\hline \multirow[t]{2}{*}{ Assets } & 1,852 & 2,455 & 2,601 & 2,088 & 1,671 & 1,376 \\
\hline & (549) & $(711)$ & (612) & $(1,173)$ & $(1,110)$ & $(1,160)$ \\
\hline \multirow[t]{2}{*}{ Debt } & 1,941 & 2,572 & 3,420 & 3,369 & 3,442 & 3,159 \\
\hline & $(442)$ & $(574)$ & (565) & $(623)$ & $(695)$ & $(693)$ \\
\hline \multirow[t]{2}{*}{ Long term } & 1,944 & 2,586 & 3,408 & 3,371 & 3,425 & 3,139 \\
\hline & $(442)$ & (563) & (563) & (619) & $(691)$ & $(689)$ \\
\hline Short term & $\begin{array}{c}-3 \\
(10)\end{array}$ & $\begin{array}{l}-14 \\
(22)\end{array}$ & $\begin{array}{l}12 \\
(8)\end{array}$ & $\begin{array}{c}-2 \\
(12)\end{array}$ & $\begin{array}{c}17 \\
(11)\end{array}$ & $\begin{array}{c}20 \\
(11)\end{array}$ \\
\hline Assets minus debt & $\begin{array}{c}-89 \\
(487) \\
\end{array}$ & $\begin{array}{l}-117 \\
(527)\end{array}$ & $\begin{array}{l}-819 \\
(623)\end{array}$ & $\begin{array}{r}-1,281 \\
(1,189)\end{array}$ & $\begin{array}{c}-1,771 \\
(1,165)\end{array}$ & $\begin{array}{r}-1,783 \\
(1,251)\end{array}$ \\
\hline
\end{tabular}

Notes: All regressions use the dynamic specification - see notes to Table 5 for details. All variables are measured in constant year-2000 dollars per pupil. 
Appendix Figure 1. Dynamic RD estimates of effect of bond passage on capital outlays per pupil, excluding district fixed effects, by years before or after election

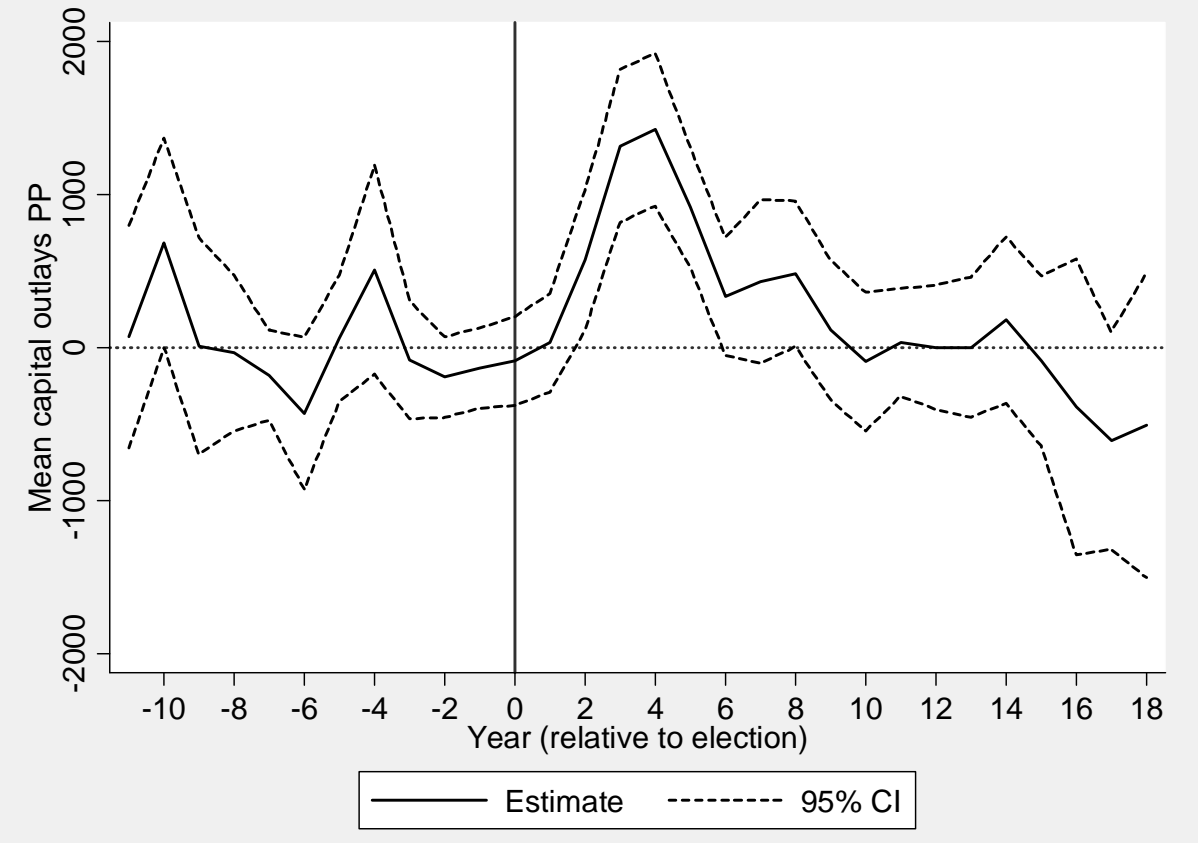

Notes: Specification is identical to that used in Table 5, Column 3, except that district fixed effects are excluded and all measure indicators, vote share polynomials, and passage indicators are interacted with a full set of indicators for years -11 through +18 . The specification in Table 5 included district effects and constrained all pre-election coefficients (i.e. all years -11 through 0 ) to zero. 